\title{
Leptomeningeal Metastases from Solid Tumors: Recent Advances in Diagnosis and Molecular Approaches
}

\author{
Alessia Pellerino ${ }^{1, *(D)}$, Priscilla K. Brastianos ${ }^{2}$, Roberta Rudà ${ }^{1,3}$ and Riccardo Soffietti ${ }^{1}$ (D) \\ 1 Department of Neuro-Oncology, University and City of Health and Science Hospital, 10126 Turin, Italy; \\ rudarob@hotmail.com (R.R.); riccardo.soffietti@unito.it (R.S.) \\ 2 Massachusetts General Hospital Cancer Center, Harvard Medical School, Boston, MA 02115, USA; \\ pbrastianos@mgh.harvard.edu \\ 3 Department of Neurology, Castelfranco Veneto and Brain Tumor Board Treviso Hospital, 31100 Treviso, Italy \\ * Correspondence: alessia.pellerino85@gmail.com; Tel.: +39-011-633-4904
}

Citation: Pellerino, A.; Brastianos, P.K.; Rudà, R.; Soffietti, R. Leptomeningeal Metastases from Solid Tumors: Recent Advances in Diagnosis and Molecular Approaches. Cancers 2021, 13, 2888. https:// doi.org/10.3390/cancers13122888

Academic Editors: Lingzhi Wang and Qiang Jeremy Wen

Received: 16 May 2021

Accepted: 5 June 2021

Published: 9 June 2021

Publisher's Note: MDPI stays neutral with regard to jurisdictional claims in published maps and institutional affiliations.

Copyright: (c) 2021 by the authors. Licensee MDPI, Basel, Switzerland. This article is an open access article distributed under the terms and conditions of the Creative Commons Attribution (CC BY) license (https:// creativecommons.org/licenses/by/ $4.0 /)$.
Simple Summary: Leptomeningeal metastases are a devastating complication of solid tumors with poor survival, regardless of the type of treatments. The limited efficacy of targeted agents is due to the molecular divergence between leptomeningeal recurrences and primary site, as well as the presence of a heterogeneous blood-brain barrier and blood-tumor barrier that interfere with the penetration of drugs into the brain. The diagnosis of leptomeningeal metastases is achieved by neurological examination, and/or brain and spinal magnetic resonance, and/or a positive cerebrospinal fluid cytology. The presence of neoplastic cells in the cerebrospinal fluid examination is the gold-standard for the diagnosis of leptomeningeal metastases; however, novel techniques known as "liquid biopsy" aim to improve the sensitivity and specificity in detecting circulating neoplastic cells or DNA in the cerebrospinal fluid. Targeted therapies and immunotherapies have changed the natural history of metastatic solid tumors, including lung, breast cancer, and melanoma. Targeting actionable mutations, such as epidermal growth factor receptor-mutated and anaplastic lymphoma kinase-gene rearranged in lung cancer, human epidermal growth factor receptor 2-positive breast cancer, and BRAF-mutated melanoma, have led to encouraging results also in leptomeningeal metastases. On the other hand, immunotherapy or modified traditional chemotherapy are under investigation in LM from non-druggable tumors.

Abstract: Leptomeningeal metastases (LM) from solid tumors represent an unmet need of increasing importance due to an early use of MRI for diagnosis and improvement of outcome of some molecular subgroups following targeted agents and immunotherapy. In this review, we first discussed factors limiting the efficacy of targeted agents in LM, such as the molecular divergence between primary tumors and CNS lesions and CNS barriers at the level of the normal brain, brain tumors and CSF. Further, we reviewed pathogenesis and experimental models and modalities, such as MRI (with RANO and ESO/ESMO criteria), CSF cytology and liquid biopsy, to improve diagnosis and monitoring following therapy. Efficacy and limitations of targeted therapies for LM from EGFRmutant and ALK-rearranged NSCLC, HER2-positive breast cancer and BRAF-mutated melanomas are reported, including the use of intrathecal administration or modification of traditional cytotoxic compounds. The efficacy of checkpoint inhibitors in LM from non-druggable tumors, in particular triple-negative breast cancer, is discussed. Last, we focused on some recent techniques to improve drug delivery.

Keywords: ALK-rearranged NSCLC; blood-brain barrier; BRAF-mutated melanoma; EGFR-mutated NSCLC; HER2-enriched breast cancer; immunotherapy; leptomeningeal metastases; liquid biopsy; triple-negative breast cancer 


\section{Introduction}

Leptomeningeal metastases (LM) are defined as the infiltration of leptomeninges, including the pia mater, arachnoid and subarachnoid space, from a primary solid tumor. LM represent the third most frequent metastatic complication of the central nervous system (CNS) after brain metastases (BM) and epidural metastases [1], with an overall survival (OS) ranging from weeks to months, regardless of the type of treatment. In this regard, autopsy series have shown the presence of undiagnosed or asymptomatic LM in 19\% of patients with solid tumors, of which $5 \%$ are an end-stage complication following systemic treatments [2]. Solid tumors with a significant risk of leptomeningeal recurrence are melanoma in 5-7\% of patients [3], non-small-cell lung cancer (NSCLC) and breast cancer in $3-5 \%$, respectively $[4,5]$. The incidence of LM is increasing due to the improvement of tools for diagnosis and monitoring, as well as the availability of more active targeted therapy to control systemic disease, while being less effective in CNS due to the presence of the blood-brain barrier (BBB). Here, we review the role of the BBB in regulating the penetration into the CNS of targeted therapy and immunotherapy and the diagnostic challenges in LM, including the role of magnetic resonance imaging (MRI), cerebrospinal fluid (CSF) cytology and liquid biopsy. Furthermore, we discuss the impact of targeted therapies in LM from solid tumors with actionable mutations, such as epidermal growth factor receptor (EGFR)-mutated and anaplastic lymphoma kinase (ALK)-gene rearranged NSCLC, human epidermal growth factor receptor 2 (HER2)-positive breast cancer (BC) and BRAF-mutated melanoma. Last, some evidence is provided on the impact of immunotherapy in LM from solid tumors without druggable mutations.

\section{The Role of the Blood-Brain Barrier, Blood-Tumor Barrier and Blood-CSF Barrier in Drug Delivery}

The BBB consists of endothelial cells (ECs) linked by tight junctions (TJs), which are surrounded by pericytes and astrocytic endfeet, that contribute to the integrity of the basal lamina. The surface of the basal lamina provides molecules that may activate multiple signaling pathways to maintain the CNS homeostasis and regulate the passage of molecules through the BBB [6]. ECs create a continuous, non-fenestrated barrier with a reduced number of pores that limit the vesicular trafficking and pinocytosis [7]. In general, molecules may cross the BBB by means of several mechanisms: (1) paracellular transport, which depends on physicochemical properties of molecules, such as molecular weight, lipophilicity and electrical charge, and remains limited to small lipophilic molecules (e.g., oxygen, caffeine) [8]; (2) transcellular transport characterized by a flow from the luminal side of the ECs to the abluminal side into the brain interstitium, using either vesicle-mediated transcytosis (receptor-mediated or adsorptive routes) or carrier-mediated transcytosis that are mainly used by small hydrophilic molecules (glucose, insulin, amino acids, albumin, infectious agents and neurotoxins) [9]. The main role of the BBB is to interfere with the penetration of exogen agents and toxins into the CNS. As for antineoplastic drugs, most small molecules and nearly $100 \%$ of large compounds have poor penetration through the BBB [10], resulting in a significant control of systemic disease, while CNS remains a frequent site of relapse [11,12]. The ATP-binding cassette transporters (ABC transporters) mediate the efflux toward the luminal space with the aim to clear brain parenchyma and CSF space from most antineoplastic compounds [13]. As ABC transporters are expressed either on ECs or astrocytes, microglia and neurons, the penetration through the BBB is not the only factor that impacts an adequate concentration of drugs into the brain parenchyma or CSF [14]. For instance, the multidrug resistant (MDR) ABC transporters, P-glycoprotein (P-gp or ABCB1), breast cancer resistance protein (BCRP or ABCG2) and multidrug resistance proteins (MRPs) affect the balance between influx and efflux and the therapeutic delivery of chemotherapy and targeted therapy [15], representing a barrier to overcome in order to improve drug concentrations in CNS.

During tumor progression in the CNS, BBB is disrupted and replaced with a dysfunctional interface represented by the blood-tumor barrier (BTB), which consists of tortuous 
vessels, an abnormal pericyte distribution and loss of astrocytic endfeet, leading to heterogeneous permeability to drugs, as well as a heterogeneous perfusion that contributes to an inadequate drug accumulation in tumor cells [16]. In this regard, pericytes present a different composition of desmin-positive subpopulations in BM/LM when compared with normal vessels of brain tissue [17]. Similarly, reactive astrocytes reduce the expression of the omega-3 fatty acid transporter for the docosahexaenoic acid (DHA) on ECs, which is necessary for neuronal function and neuroprotection, leading to the loss of the endfeet connection with the ECs [18]. Moreover, the increased expression of the sphingosine 1phosphate receptor 3 (S1PR3) on reactive astrocytes determines a loss of the interaction with BTB via interleukin-6 (IL6) and CC chemokine ligand 2 (CCL2) secretion, resulting in a leakier and heterogenous permeability to drugs [19]. Importantly, the BBB/BTB interface may differ among BM/LM from different subtypes of solid tumors. For instance, the BTB of CNS recurrences from HER2-positive $B C$ retains a higher expression of glucose transporter 1 (GLUT1) and BCRP compared with other molecular subtypes [20]. Preclinical models have shown that the small molecule lapatinib has a different distribution in BM from HER2enriched BC and healthy brain tissue [21]. Table 1 displays some examples of BBB/BTB heterogeneity in preclinical and clinical studies in CNS metastases from solid tumors.

Table 1. Blood-brain barrier/blood-tumor barrier heterogeneity in preclinical and clinical studies.

\begin{tabular}{c}
\hline Preclinical Models \\
\hline NSCLC \\
\hline BM models using the ALK-rearranged NSCLC cell line H3122 EML4-ALK ${ }^{\mathrm{L} 1196 \mathrm{M}}$ showed that the PF-06463922 compound is a \\
potent brain-permeable ALK/ROS1 inhibitor with an increased ability to cross the BBB/BTB and penetrate into non-permeable \\
micrometastases and macrometastases [22]
\end{tabular}

\section{Melanoma}

An in vivo longitudinal MRI study using contrast-enhanced T1-weighted spin echo images was performed after the intracardiac injection of melanoma cell lines A2058 in mice, reporting the presence in BM of regions with intact BBB mixed with other areas with a disrupted BBB [23]

BM models from melanoma cells (MDA-MB-435 and A2058) show vessel cooperation between tumor cells and BTB, while models using NSCLC cells (PC14-PE6 and HTB177) enhance the neoangiogenesis to alter the BBB/BTB [24]

\section{Breast Cancer (BC)}

After the intracardiac injection of BC cell lines 231-BR-HER2 and 4T1-BRS, the BTB permeability differs between the two models: the 231-BR model showed a significant permeability to drugs because of the high expression of S1PR-3 [19]

The BBB is more permeable in cell models using SUM190-BR3 and JIMT-1-BR3 BC cells compared with the 231-BR-HER2 counterpart [25]

Desmin-positive pericytes correlate with areas of high permeability on BTB from BC [17]

Intracranial injection model using human BC cell line BT474 is permeable to chemotherapy and antibodies in physiological conditions, but the drug delivery significantly increases after the BBB/BTB disruption [26]. Such a preclinical model has been reproduced in a clinical setting demonstrating a comparable drug delivery of targeted therapy (lapatinib) in BM and primary site [27]. Furthermore, intracranial injection of BT474 cells creates a leakier BBB/BTB and an increased drug uptake compared with

intravenously or intracardially injection models, displaying that the route of administration significantly impacts the drug delivery [28]

\section{Miscellanea}

Some patient-derived xenograft models of CNS recurrences from NSCLC, BC, melanoma, prostate and neuroendocrine tumors revealed a decreased expression of NLS1 on BBB compared with healthy brain tissue [18]

\section{Clinical Data \\ Breast Cancer}

$\mathrm{BBB} / \mathrm{BTB}$ interface is different according to molecular subtypes of BC. HER2-enriched cells tend to preserve the integrity of the BBB, while TNBC or basal-type BC disrupt the BBB. Moreover, the ECs of BTB express higher levels of GLUT1 and BCRP compared with those ER-positive or TNBC [20] 
Table 1. Cont.

Preclinical Models

Lapatinib achieves significant concentrations (1.0-6.5 microM) from HER2-positive BM when administered at a daily dose of $1250 \mathrm{mg}$ (last dose 2-3 h before surgery) [29]. This evidence was confirmed by PET studies when comparing tumors with normal brain tissue [30]. Although HER2-positive BM preserve the integrity of BBB, trastuzumab alone or linked to emtansine (TDM-1) achieves a significant distribution due to the leakiness of the BTB [31,32]

NSCLC: non-small-cell lung cancer; BM: brain metastasis; ALK: anaplastic lymphoma kinase; BBB: blood-brain barrier; BTB: blood-tumor barrier; MRI: magnetic resonance imaging; CNS: central nervous system; NLS1: sodium-dependent lysophosphatidylcholine symporter 1; TNBC: triple-negative breast cancer; ECs: endothelial cells; GLUT1: glucose transporter 1; BCRP: breast cancer resistance protein; ER: estrogen receptor; PET: positron emission tomography.

A further barrier that limits the penetration of compounds is represented by the bloodCSF barrier, which comprises the TJs between choroid plexus epithelial cells. Since the BBB and blood CSF barrier use different active transport mechanisms to regulate the passage of molecules, and CSF drug concentrations depend on the permeability of the blood-CSF barrier, drug delivery into CNS cannot be considered as a surrogate of drug concentrations in LM [9]. The absence of a reliable tool to determine whether drugs adequately cross the BBB is the main goal of future phase 0 trials with the aim to investigate the drug target effects, as well as the pharmacokinetic-pharmacodynamic features in an early clinical setting [33].

\section{Pathogenesis of Leptomeningeal Metastases}

Four main routes favor the leptomeningeal dissemination from solid tumors: (i) hematogenous spread through arterial vessels; (ii) venous circulation through bridging venous or the Batson's plexus, which is a network of veins that connect the deep pelvic and thoracic veins and drain blood from the urinary bladder, breast and prostate to the internal vertebral venous plexuses; (iii) the neural route through cranial nerves or spinal roots; and (iv) from the brain parenchyma by contiguity. The arterial and venous routes are considered the major routes used by NSCLC and BC to spread, while the perineural route has been associated with melanoma $[34,35]$. Some iatrogenic dissemination to leptomeninges may occur after surgery of BM, especially in the posterior fossa, using a piecemeal compared with en bloc tumor resection or when access to the ventricular system is required [36]. Moreover, stereotactic radiosurgery (SRS), especially when treating a resection cavity, has been suggested to increase the risk of local LM up to $31 \%$, although the data in this area are still limited and need to be explored $[37,38]$.

New insights in the molecular mechanisms underlying LM development are emerging. Boire et al. reported that complement component 3 (C3), which is produced by tumor cells in the CSF, is overexpressed in LM models of NSCLC and BC. C3 interacts with the $\mathrm{C} 3 a$ receptor $(\mathrm{C} 3 \mathrm{aR})$ on the epithelial cells of the choroid plexus, perturbs the barrier function and allows the passage of mitogen factors, such as amphiregulin, that drive tumor growth in leptomeninges. When $\mathrm{C} 3 \mathrm{aR}$ signaling is blocked using a specific antagonist, LM development is suppressed [39]. Similarly, Conrad et al. reported that matrix metalloproteinases (MMPs) type 9 and a disintegrin and metalloproteases (ADAMs) type 8-17 are markers of extracellular matrix degradation in CSF following leptomeningeal dissemination and blood-CSF barrier disruption, promoting the entry of tumor cells in subarachnoid space [40]. Furthermore, tumor cells gain some mechanisms for surviving in a CSF microenvironment with poor micronutrients. CSF samples from five patients with LM were analyzed using single-cell RNA sequencing, showing that tumor cells, but not macrophages, within the CSF express the iron-binding protein lipocalin-2 (LCN2) and its receptor SCL22A17. These macrophages produce inflammatory cytokines that stimulate LCN2 expression on tumor cells but do not generate LCN2 themselves. In mouse models of LM, when iron levels are reduced by chelation therapy, tumor cell growth is inhibited, suggesting that cancer cells survive in the CSF by outcompeting macrophages for iron [41]. Notably, Remsik et al. [42] used leptomeningeal derivatives of human breast and lung cancer to show that tumor cells in CSF may have a floating or adherent phenotype: the floating phenotype corresponds to disease in the CSF, while the adherent phenotype is 
enhancing on MRI. Tumor cells of the floating phenotype have a decreased proliferation rate, lower ATP content and are enriched of peculiar metabolic signatures, such as tricarboxylic acid cycle and electron transport chain signatures, resulting in a metabolic flexibility of LM cells in adapting to the limited glucose levels in the CSF. Furthermore, the floating cells disseminate into mouse leptomeninges earlier and are associated with a shorter survival in comparison with the adherent phenotype. Some studies have shown the development of LM from BC and NSCLC close to BM using murine models. Palmieri and Allen reported the ability of brain-metastatic MDA-MB-231 cells to generate both HER2-positive parenchymal and leptomeningeal disease from BC after intracardiac injection [43,44]. Recently, Dankner et al. [45] reported a different propensity to LM based on the pattern of invasion in BM (minimally invasive versus highly invasive), which is driven by the expression of the cold-inducible RNA-binding protein (CIRBP). These data suggest that specific molecular pathways are present in a subset of BM cells only and are involved in leading the invasion of leptomeninges. Another molecular mechanism associated with leptomeningeal spreading is the acquired resistance to first-generation targeted therapy. In this regard, Nanjo et al. displayed that the acquired resistance to gefitinib in LM from NSCLC is associated with an overexpression of MET proto-oncogene and a lack of T790 mutation [46]. In fact, T790 mutation has not been detected in LM or the CSF of patients pretreated with EGFR tyrosine kinase inhibitors (TKIs) [47,48], and Jiang et al. reported a low frequency (21\%) of T790 mutation and a high prevalence (39\%) of MET amplification in the CSF [49], arguing that MET amplification and absence of T790 mutation may be hallmarks of leptomeningeal invasion [50].

A further factor limiting the efficacy of targeted agents in LM may be the potential molecular divergence between primary tumors and CNS lesions. Brastianos et al. [51] demonstrated that specific genetic alterations were not found in the matched-primary tumor sample in $53 \%$ of BM from BC, NSCLC and renal cancer. However, spatially and temporally separated BM were more genomically homogeneous. BM shared PI3K/AKT/mTOR, CDK and HER2/EGFR mutations. Further investigations displayed that the amplification of MYC, YAP1 and MMP13 and the deletion of CDKN2A/B are frequent genetic aberrations in BM from NSCLC; however, it is unknown whether they play a key role in leptomeningeal dissemination [52]. Molecular divergence has also been reported in BM from BC. Approximately $16-22 \%$ of BM from HER2-negative BC have been reported to gain HER2 amplifications and EGFR overexpression [43,53], as well as PTEN loss [54], compared with the primary site. Overall, the molecular profiling of CNS recurrence and the primary tumor should be necessary to choose the most adequate treatment. However, surgery is not always feasible, especially in LM; thus, alternative techniques to predict molecular subtypes, such as liquid biopsy, need to be developed.

\section{Diagnosis of Leptomeningeal Metastases}

The diagnosis of LM is achieved by combining neurological evaluation, an MRI of the brain and spinal axis and/or the identification of tumor cells in the CSF, which is the gold standard for diagnosis. The European Association of Neuro-Oncology-European Society of Medical Oncology (EANO-ESMO) group has proposed a diagnostic flowchart that includes neurological symptoms, imaging and CSF cytology for diagnosis, treatment and follow-up of patients with LM from solid tumors [55]. The combination of these three items allows one to define the diagnosis of LM as type I with positive CSF cytology or type II (probable/possible) with typical MRI characteristics and neurological signs. Based on the MRI pattern, LM may be defined as linear (subtype A), nodular (subtype B), both (subtype C) or hydrocephalus (subtype D). Recently, the EANO-ESMO group has retrospectively reviewed $254 \mathrm{LM}$ from solid tumors using the aforementioned guidelines, reporting a remarkable prognostic value in predicting OS. In particular, patients with type I have a shorter OS than type II LM. Concerning MRI findings, nodular disease negatively impacts survival in type II but not in type I LM. Lastly, the administration of either systemic or intrathecal therapy is associated with improved OS in type I, but not in type II LM, although 
this needs to be explored in bigger datasets and prospective trials. Overall, the EANOESMO LM classification is highly prognostic and has been recommended for stratification and design of clinical trials [56].

\subsection{Neurological Symptoms}

Symptoms of LM are typically multifocal reflecting the involvement of spinal cord and nerve roots in $60 \%$ of patients, cranial nerves in $35 \%$ and the cerebrum in $15 \%$. The differential diagnosis includes symptoms associated with BM or other conditions, such as treatment-related toxicities or neurological paraneoplastic syndromes. Headache and nausea (66\%), spinal and/or radicular symptoms (46\%), diplopia, visual impairment and hearing loss (36\%) are the most frequent symptoms of LM, while dysphagia, mental changes and seizures are late signs of encephalopathy, which correlate with poor outcome [34]. The Leptomeningeal Assessment in Neuro-Oncology (LANO) group has proposed a standardized assessment for the neurological examination with multiple domains, including gait, strength, sensation, vision, eye movement, facial strength, hearing, swallowing, level of consciousness and behavior, with the aim to be utilized by neurologists, neuro-oncologists, medical oncologists, nurses and physician assistants, but it needs to be prospectively validated [57].

\subsection{Neuroimaging Assessment}

Brain and spinal MRIs are the current methods for the diagnosis of LM [55], which may present different patterns of enhancement, such as nodular, linear or curvilinear, as well as focal or diffuse features, with a significant inter-observer variability to classify the lesions [58] (Figures 1-3). The integration of MRI findings and CSF cytology helps to better stratify patients: patients with type 2A or 2C nodular LM lesions have a worse OS compared with those with non-nodular disease [56]. Conversely, the presence of nodular LM is associated with an improved OS in patients with BM treated with surgery followed by adjuvant SRS when compared with diffuse linear LM [59-61]. Furthermore, the pattern of enhancement is not the unique radiological factor that impacts the outcome, but also the location of LM has been suggested to influence the prognosis. In fact, patients with only cranial involvement display a better outcome than those with both cranial and spinal LM [62].

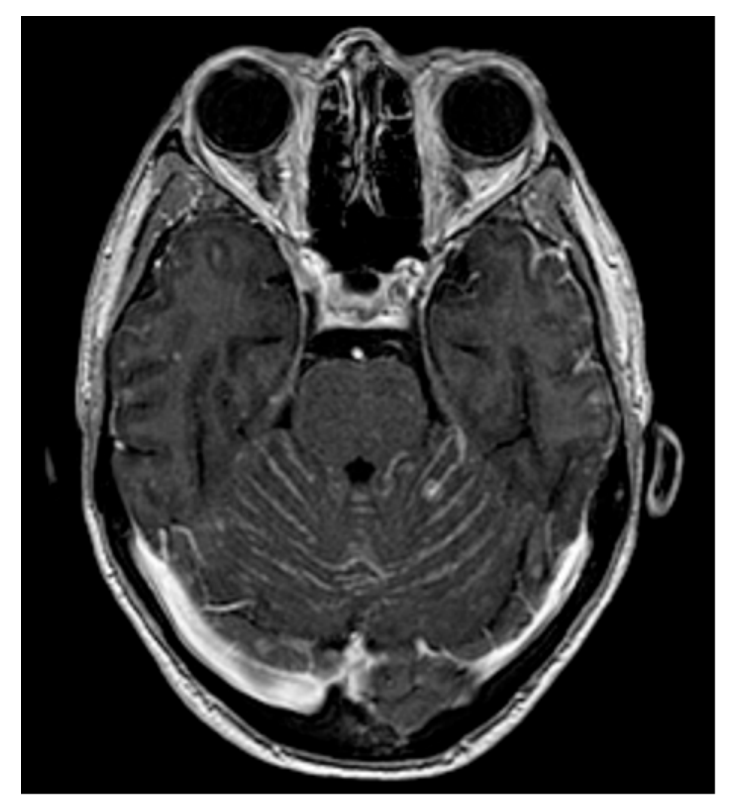

Figure 1. Cerebellar localizations of a HR-positive/HER2-negative breast cancer following CDK4/6 inhibitor palbociclib. 


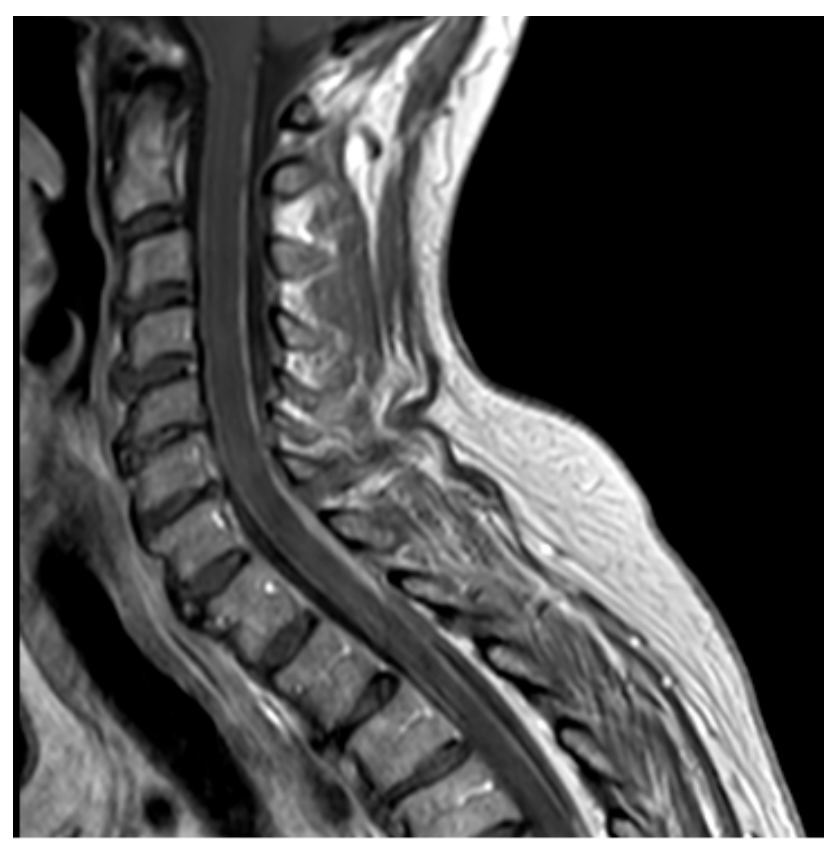

Figure 2. Cervical leptomeningeal carcinomatosis of an ALK-rearranged NSCLC after failure of the first- and second-generation ALK inhibitors (crizotinib and alectinib, respectively).

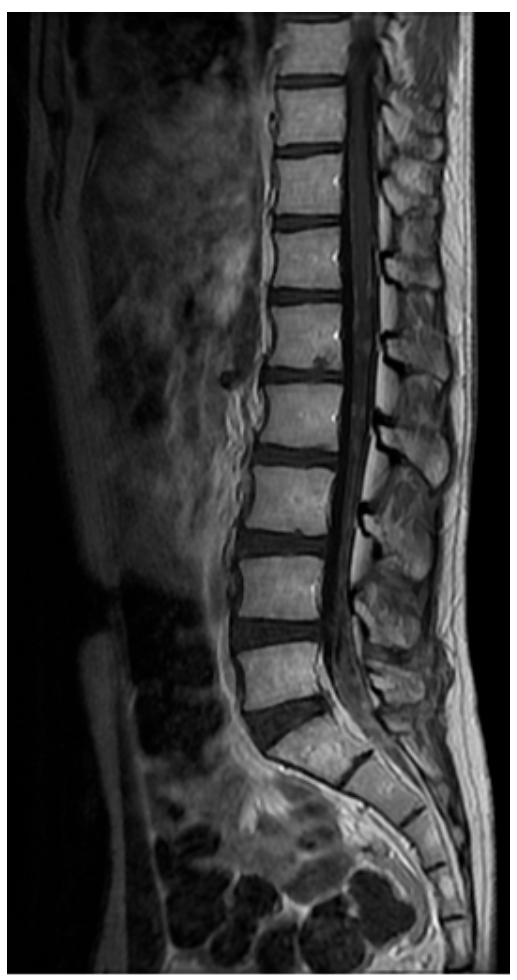

Figure 3. Leptomeningeal metastases of the cauda equina from a BRAFv600-mutated melanoma.

\subsection{CSF Cytology and Liquid Biopsy}

The identification of neoplastic cells in CSF is the gold standard for the diagnosis of LM, and the presence of a positive CSF cytology is correlated with a worse OS [56]. However, the sensitivity of CSF cytology is limited to $44-67 \%$ at the first lumbar puncture and increases to $84-91 \%$ after repeated sampling [63-68]. Moreover, the presence of "suspicious" or "atypical" cells may impact the sensitivity and specificity of conventional CSF cytology [69]. Hence, some novel techniques have been developed to improve the 
detection of circulating tumor cells (CTCs) in the CSF using immunoflow cytometry with fluorescently labeled antibodies against membrane-bound tumor cell proteins, such as the epithelial cell adhesion molecule (EpCAM) for epithelial tumor cells [70], and human high molecular weight-melanoma-associated antigen (HMW-MAA/MCSP) or melanoma chondroitin sulfate proteoglycan (MCSP) and CD146 for melanoma [71,72]. The CellSearch platform is a method of EpCAM-based rare cell capture technology (RCCT), which uses an immunomagnetic CTC selection using EpCAM antibody conjugated ferroparticles, able to provide a quantitative assessment of cancer cells in a limited amount of CSF (3 cc). Some studies using immunoflow cytometry or an adapted CellSearch technique for searching for CTCs in the CSF report a sensitivity ranging from 75 to $100 \%$ and a specificity of $84-100 \%$ (Table 2). However, these studies have major limitations, including a small sample size, and mainly focused on NSCLC and BC. Data on sensitivity and specificity of the CellSearch platform based on immunofluorescence detection of HMW-MAA, CD45 and CD34 for patients with melanoma were reported in two patients only [72] due to the decision of the company to not pursue further development of the technique. Moreover, it is unknown whether immunoflow cytometry and CellSearch technology are comparable in terms of detecting CTCs. As epithelial tumor cells can lose EpCAM expression due to the transition to mesenchymal subtype [73] and HMW-MAA/MCSP expression on melanoma cells is only found in 85\%, both EpCAM and HMW-MAA/MCSP assays could fail in detecting CTCs. In light of that, the CSF cytology may help to increase the specificity when the CTC assay is negative. An advantage of detecting CTCs is to provide data on tumor burden, while CSF cytology cannot provide quantitative information. Some small studies have demonstrated a correlation of quantification of CTCs in CSF and the prediction of survival in LM $[72,74,75]$, but the cutoff value needs to be validated in larger and prospective cohorts. Another advantage of CTCs is to isolate single CTCs for searching genetic aberrations that are shared by primary solid tumors. In this regard, CTCs from the CSF of patients with LM from EGFR-mutated or ALK-rearranged NSCLC have a highly concordant molecular profile (89.5\%) with a paired primary tumor [76]. Conversely, Magbanua and Li performed a genomic sequencing on isolated $\mathrm{BC}$ cells in the CSF of patients and reported some shared mutations with the primary $\mathrm{BC}$, as well as new mutations, suggesting a molecular divergence in LM $[77,78]$. Importantly, some of these distinct mutations, such as syndecan-1 and MUC-1 overexpression, have been correlated to leptomeningeal invasion [79].

Table 2. Studies on circulating tumor cells in CSF from LM.

\begin{tabular}{|c|c|c|c|}
\hline Study & $\begin{array}{c}\text { Number of } \\
\text { Patients }\end{array}$ & Type of Primary Solid Tumor & Results \\
\hline Patel et al., 2011 [74] & 5 & $\mathrm{BC}$ & $\begin{array}{l}\text { CTCs detected using CellSearch technique } \\
\text { showing that the number of CTCs are } \\
\text { correlated with leptomeningeal burden and } \\
\text { response to chemotherapy }\end{array}$ \\
\hline LeRhun et al., 2012 [80] & 8 & $\mathrm{BC}$ & $\begin{array}{l}\text { Detection of CTCs with adapted CellSearch } \\
\text { technology displays a quantitative } \\
\text { correlation with the response to therapy }\end{array}$ \\
\hline Subirà et al., 2012 [63] & 72 & $\begin{array}{l}\text { BC (44) } \\
\text { NSCLC (23) } \\
\text { GIC (4) } \\
\text { Cavum (1) }\end{array}$ & $\begin{array}{l}\text { Sensitivity of CTCs: } 75.5 \% \\
\text { Sensitivity of CSF cytology: } 65.3 \% \\
\text { Specificity of CTCs: } 96.1 \% \\
\text { Specificity of CSF cytology: } 100 \% \\
\text { Immunoflow cytometry }\end{array}$ \\
\hline
\end{tabular}


Table 2. Cont.

\begin{tabular}{|c|c|c|c|}
\hline Study & $\begin{array}{c}\text { Number of } \\
\text { Patients }\end{array}$ & Type of Primary Solid Tumor & Results \\
\hline Nayak et al., 2013 [64] & 51 & $\begin{array}{l}\text { NSCLC (21) } \\
\text { BC (15) } \\
\text { Melanoma (1) } \\
\text { Ovarian cancer (2) } \\
\text { Others (12) }\end{array}$ & $\begin{array}{l}\text { Sensitivity of CTCs: } 100 \% \\
\text { Sensitivity of CSF cytology: } 66.7 \% \\
\text { Specificity of CTCs: } 97.2 \% \\
\text { Specificity of CSF cytology: } 100 \% \\
\text { Median CTCs: } 20.7 \text { cells/mL } \\
\text { CellSearch technique }\end{array}$ \\
\hline LeRhun et al., 2013 [72] & 2 & Melanoma & $\begin{array}{l}\text { First study that used adapted CellSearch } \\
\text { technology against HMW-MAA to detect } \\
\text { melanoma CTCs }\end{array}$ \\
\hline Lee et al., 2015 [66] & 38 & $\mathrm{BC}$ & $\begin{array}{l}\text { Sensitivity of CTCs: } 80.9 \% \\
\text { Sensitivity of CSF cytology: } 66.7 \% \\
\text { Specificity of CTCs: } 84.6 \% \\
\text { Specificity of CSF cytology: } 100 \% \\
\text { CellSearch technique }\end{array}$ \\
\hline Subirà et al., 2015 [65] & 144 & $\begin{array}{l}\text { BC (39) } \\
\text { NSCLC (35) } \\
\text { GIC (6) } \\
\text { Ovarian (4) } \\
\text { Prostate (3) } \\
\text { Others (5) }\end{array}$ & $\begin{array}{l}\text { Sensitivity of CTCs: } 79.8 \% \\
\text { Sensitivity of CSF cytology: } 50.0 \% \\
\text { Specificity of CTCs: } 84.0 \% \\
\text { Specificity of CSF cytology: } 100 \% \\
\text { Immunoflow cytometry }\end{array}$ \\
\hline Tu et al., 2015 [67] & 18 & NSCLC & $\begin{array}{l}\text { Sensitivity of CTCs: } 77.8 \% \\
\text { Sensitivity of CSF cytology: } 44.4 \% \\
\text { Specificity of CTCs: } 100 \% \\
\text { Specificity of CSF cytology: not reported } \\
\text { CellSearch technique }\end{array}$ \\
\hline Acosta et al., 2016 [81] & 6 & Epithelial cell tumors & $\begin{array}{l}\text { Sensitivity of CTCs: } 100.0 \% \\
\text { Specificity of CTCs: } 100.0 \% \\
\text { Immunoflow cytometry }\end{array}$ \\
\hline $\begin{array}{l}\text { Milojkovic Kerklaan et al., } \\
2016 \text { [68] }\end{array}$ & 29 & Epithelial cell tumors & $\begin{array}{l}\text { Sensitivity of CTCs: } 100.0 \% \\
\text { Sensitivity of CSF cytology: } 61.5 \% \\
\text { Specificity of CTCs: } 100.0 \% \\
\text { Specificity of CSF cytology: } 100 \% \\
\text { Immunoflow cytometry }\end{array}$ \\
\hline Ma et al., 2016 [82] & 10 & NSCLC & $\begin{array}{l}\text { Seven out of ten CSF samples where CTCs } \\
\text { were found with a range from } 3 \text { to } \\
1823 \text { tumor cells } \\
\text { TM-iFISH }\end{array}$ \\
\hline Jiang et al., 2017 [76] & 21 & NSCLC & $\begin{array}{l}\text { Sensitivity of CTCs: } 95.2 \% \\
\text { Sensitivity of CSF cytology: } 57.1 \% \\
\text { Specificity of CTCs: } 100 \% \\
\text { Specificity of CSF cytology: not reported } \\
\text { CellSearch technique }\end{array}$ \\
\hline Lin et al., 2017 [83] & 95 & $\begin{array}{l}\text { NSCLC (36) } \\
\text { BC (31) } \\
\text { Others (28) }\end{array}$ & $\begin{array}{l}\text { Sensitivity of CTCs: } 93.0 \% \\
\text { Sensitivity of CSF cytology: } 29.0 \% \\
\text { Specificity of CTCs: } 95.0 \% \\
\text { Specificity of CSF cytology: not reported } \\
\text { CellSearch technique }\end{array}$ \\
\hline
\end{tabular}


Table 2. Cont.

\begin{tabular}{|c|c|c|c|}
\hline Study & $\begin{array}{c}\text { Number of } \\
\text { Patients }\end{array}$ & Type of Primary Solid Tumor & Results \\
\hline van Bussel et al., 2020 [84] & 81 & NSCLC & $\begin{array}{l}\text { Sensitivity of CTCs: } 94.0 \% \\
\text { Specificity of CTCs: } 100.0 \% \\
\text { Cut-off for CTCs positivity: } 0.9 \text { CTC } / \mathrm{mL} \\
\text { Immunoflow cytometry }\end{array}$ \\
\hline Nevel et al., 2020 [75] & 16 & NSCLC & $\begin{array}{l}\text { Patients with } \geq 50 \mathrm{CTCs} / 3 \mathrm{~mL} \text { had an } \\
\text { increased risk of death in comparison with } \\
\text { that of those with }<\mathrm{CTCs} / 3 \mathrm{~mL} \\
\text { CellSearch technique }\end{array}$ \\
\hline Malani et al., 2020 [85] & 15 & HER2-positive BC & $\begin{array}{l}\text { CSF CTCs were identified in } 13 \text { patients } \\
(87 \%) \\
\text { Median CSF CTCs was } 22 \text { CTCs } / 3 \mathrm{~mL} \text { (range } \\
0-200+\text { ). } \\
\text { HER2 expression analysis of CTCs was } \\
\text { performed in } 8 \text { patients; } 75 \% \text { had confirmed } \\
\text { expression of HER2 in CSF } \\
\text { CellSearch technique }\end{array}$ \\
\hline
\end{tabular}

BC: breast cancer; CTCs: circulating tumor cells: NSCLC: non-small-cell lung cancer; GIC: gastrointestinal cancer: CSF: cerebrospinal fluid; HMW-MAA: human high molecular weight-melanoma-associated antigen; TM-iFISH: tumor marker-immunostaining fluorescence in situ hybridization; HER2: human epidermal growth factor receptor 2.

Typically, CSF is enriched with cell-free tumor DNA (ctDNA), which can be extracted and analyzed using digital PCR for a limited number of genes or undergo whole-exome sequencing based on the clinical question. Of note, the use of ctDNA from CSF has been reported to be more sensitive compared with the blood for the detection of druggable mutations in BM from solid tumors. In this regard, EGFR, PTEN, ESR1, FGFR2 and ERBB2 were more frequently detected in CSF ctDNA than in blood in a cohort of NSCLC and BC [86] as well as in patients with melanoma and negative CSF cytology [87]. Pentsova et al. found targetable mutations in the CSF of $20 / 32$ patients $(63 \%)$ with BM, while no mutations were detected in patients without CNS involvement [88]. Because cellular material in the CSF contains both normal and cancer cell DNA, extracting from the acellular material gives a significant amount of DNA from tumor cells [88]; thus, the detection of ctDNA in LM holds promise (Table 3). Momtaz et al. extracted and sequenced ctDNA from three out of three patients with confirmed radiological LM from BRAF-mutated disease, including melanoma [87]. Marchiò et al. isolated ctDNA with KRAS mutation from the CSF of two patients with LM from NSCLC, but not in blood [89]. In addition, Swinkles et al. found a mutation of KRAS using PCR sequencing in LM of patients with a negative CSF cytology, suggesting that the early detection of ctDNA may influence the prognosis [90]. CtDNA was also successfully detected in $11(100 \%)$ [91] and 28 patients $(92 \%)$ with LM from EGFR-mutated NSCLC [92]. However, some technical issues must be considered: most of the studies used digital PCR or targeted sequencing of a limited number of genes and did not cover the whole range of the targetable mutations. Moreover, copy-number mutations and some gene translocations and fusions, such as ALK-rearrangement, may be not detected using the standard "off the shelf" whole-exome sequencing. In addition, most clinical institutions do not have the professional and technical resources to perform the analyses "in house"; thus, samples must be sent to other adequately equipped facilities, and issues of sample managing, storage and shipment must be addressed [93]. 
Table 3. Studies on circulating tumor DNA in CSF from LM.

\begin{tabular}{|c|c|c|c|}
\hline Study & $\begin{array}{l}\text { Number of } \\
\text { Patients }\end{array}$ & $\begin{array}{l}\text { Type of Primary Solid } \\
\text { Tumor }\end{array}$ & Results \\
\hline $\begin{array}{l}\text { Swinkels et al., } \\
\quad 2000[90]\end{array}$ & 2 & NSCLC & $\begin{array}{l}\text { KRAS mutation was found in CSF of } 2 / 2 \text { patients }(100 \%) \\
\text { CSF Mutant-allele-specific amplification (PCR) }\end{array}$ \\
\hline $\begin{array}{l}\text { Momtaz et al., } \\
\quad 2016[87]\end{array}$ & 11 & $\begin{array}{l}\text { BRAF-mutated } \\
\text { malignancies }\end{array}$ & $\begin{array}{l}\text { BRAF mutations detected in CSF-ctDNA of } \\
6 / 11 \text { patients }(54 \%) \\
\text { Droplet digital sequencing }\end{array}$ \\
\hline $\begin{array}{l}\text { Pentsova et al., } \\
\quad 2016[88]\end{array}$ & $\begin{array}{c}32 \mathrm{BM} \\
9 \mathrm{LM}\end{array}$ & $\begin{array}{l}\text { NSCLC (11) } \\
\text { BC (11) } \\
\text { Melanoma (6) } \\
\text { Others (13) }\end{array}$ & $\begin{array}{l}\text { Mutations were detected in CSF-ctDNA of } \\
20 / 32 \text { patients }(63 \%) \text { with BM and } 3 / 4 \text { patients }(75 \%) \\
\text { with LM } \\
\text { Targeted sequencing }\end{array}$ \\
\hline $\begin{array}{l}\text { Marchio et al., } \\
\quad 2017 \text { [89] }\end{array}$ & 2 & NSCLC & $\begin{array}{l}\text { KRAS mutations detectable in CSF-ctDNA of } \\
2 / 2 \text { patients }(100 \%) \\
\text { Targeted sequencing }\end{array}$ \\
\hline Fan et al., 2018 [91] & 11 & EGFR-mutated NSCLC & $\begin{array}{l}\text { EGFR mutations were found in CSF-ctDNA of } \\
11 / 11 \text { patients }(100 \%) \text {. Mutations were not concordant } \\
\text { in } 1 / 11(9 \%) \\
\text { Targeted sequencing }\end{array}$ \\
\hline Li et al., 2018 [92] & 42 & EGFR-mutated NSCLC & $\begin{array}{l}\text { Distinct EGFR mutations were found in CSF-ctDNA of } \\
28 \text { patients }(92 \%) \\
\text { Targeted sequencing }\end{array}$ \\
\hline $\begin{array}{l}\text { Huang et al., } \\
2019 \text { [94] }\end{array}$ & $\begin{array}{l}20 \mathrm{BM} \\
15 \mathrm{LM}\end{array}$ & EGFR-mutated NSCLC & $\begin{array}{l}\text { EGFR mutations were detected in } 23 / 35 \text { patients: } \\
\text { BM: blood: } 6 / 11(54.5 \%) \text {; CSF: } 5 / 10(50 \%) \\
\text { LM: blood: } 4 / 11(36.4 \%) \text {; CSF: } 9 / 12(75 \%) \\
\text { T790 mutation was significantly higher in blood }(9 / 23) \\
\text { than that of CSF }(3 / 23) \\
\text { Sensitivity in CSF: } 56 \% \text {; in blood: } 89 \% \\
\text { Specificity in CSF: } 46 \% \text {; in blood: } 100 \% \\
\text { Twelve patients received a first-generation TKI after the } \\
\text { detection of actionable mutation in CSF, while } 5 \text { patients } \\
\text { switched to osimertinib after the detection of T790 } \\
\text { mutation in CSF or blood } \\
\text { Droplet digital PCR }\end{array}$ \\
\hline Ma et al., 2020 [95] & 11 & $\begin{array}{l}\text { NSCLC that progressed } \\
\text { after 3rd generation TKIs }\end{array}$ & $\begin{array}{l}\text { CSF-ctDNA was identified in } 8 / 11 \text { patients }(72.7 \%) \text { and } \\
\text { in the blood of } 6 / 11(54.5 \%) \\
\text { EGFR C797 mutation and MET amplification were } \\
\text { found in CSF of } 4 / 11 \text { patients ( } 36.3 \%) \text { and in the blood } \\
\text { of } 2 / 11(18.2 \%) \\
\text { One patient only had C797 and T790 mutation } \\
\text { concurrently } \\
\text { Longitudinal assessment with CSF-ctDNA displayed } \\
\text { that the level of C797 mutation decreased with } \\
\text { radiological and neurological improvement, while the } \\
\text { blood level of T790 mutation increased early before } \\
\text { leptomeningeal progression } \\
\text { Nanowire-based ctDNA assay }\end{array}$ \\
\hline Li et al., 2020 [96] & 18 & $\begin{array}{l}\quad \text { NSCLC } \\
\text { EGFR-mutated (11) } \\
\text { ALK-rearranged (6) } \\
\text { ROS1-mutated (1) }\end{array}$ & $\begin{array}{l}\text { The MET mutational rate was higher in CSF }(100 \%) \text { than } \\
\text { that of blood }(66.7 \%) \\
\text { A higher number of SNVs and copy number variants } \\
\text { were found in CSF in comparison with blood } \\
\text { SNVs were higher in patients pretreated with } \geq 2 \text { TKIs } \\
\text { than that of those who received } 1 \text { TKI only } \\
\text { NGS }\end{array}$ \\
\hline
\end{tabular}


Table 3. Cont.

\begin{tabular}{|c|c|c|c|}
\hline Study & $\begin{array}{l}\text { Number of } \\
\text { Patients }\end{array}$ & $\begin{array}{c}\text { Type of Primary Solid } \\
\text { Tumor }\end{array}$ & Results \\
\hline $\begin{array}{l}\text { Nevel et al., } \\
2020 \text { [75] }\end{array}$ & 21 & NSCLC & $\begin{array}{l}\text { CSF-ctDNA concentrations ranged from } \\
0.093 \mathrm{pg} / \mathrm{microL} \text { to } 0.562 \mathrm{ng} / \mathrm{microL} \\
\text { Median CSF-ctDNA concentration was } 0.022 \mathrm{ng} / \mathrm{microL} \\
\text { An increased risk of death was observed when ctDNA } \\
\text { concentrations were higher than the median cutpoint } \\
\text { Targeted exome sequencing MSKCC IMPACT }\end{array}$ \\
\hline $\begin{array}{l}\text { Zheng et al., } \\
\text { 2021 [97] }\end{array}$ & 80 & $\begin{array}{l}\text { EGFR-mutated NSCLC } \\
\text { Cohort 1: CSF and blood } \\
\text { genotyping before the 1st } \\
\text { administration of } \\
\text { osimertinib (45) } \\
\text { Cohort 2: CSF genotyping } \\
\text { at the time of progression } \\
\text { with LM during treatment } \\
\text { with osimertinib (35) }\end{array}$ & $\begin{array}{l}\text { Detection of actionable EGFR mutations in CSF-ctDNA: } \\
\text { Cohort 1: } 42 / 45(93.3 \%) \\
\text { Cohort 2: } 34 / 35(97.1 \%) \\
\text { Median iPFS was higher in patients with EGFR exon } \\
19 \text { deletion (11.9 months) compared with that of patients } \\
\text { harboring EGFR exon } 21 \text { L858 mutation ( } 2.8 \text { months) } \\
\text { Median iPFS was higher in patients with EGFR } \\
\text { T790-positive CSF genotyping ( } 15.6 \text { months) than that of } \\
\text { those without T790 mutation ( } 7.0 \text { months) } \\
\text { Concomitant presence of CD } 42 \text { ( } 2.8 \text { months) and } \\
\text { CDKN2a mutations ( } 2.5 \text { months) confers a shorter iPFS } \\
\text { (11.6 and 9.6 months, respectively) than that of patients } \\
\text { with CSF-ctDNA negative } \\
\text { Cohort 2: EGFR C795 mutation, MET dysregulation, } \\
\text { co-occurrence of TP53 and RB1 mutations as well as loss } \\
\text { of T790 mutation in CSF-ctDNA were correlated with } \\
\text { shorter survival } \\
\text { NGS }\end{array}$ \\
\hline $\begin{array}{l}\text { Carausu et al., } \\
2019 \text { [98] }\end{array}$ & 1 & $\begin{array}{l}\text { HR-positive/HER2- } \\
\text { negative } \\
\text { BC }\end{array}$ & $\begin{array}{l}\text { First report of detection of CSF-ctDNA of ESR1 } \\
\text { mutation after treatment with aromatase inhibitor } \\
\text { Droplet digital PCR }\end{array}$ \\
\hline $\begin{array}{l}\text { Angust et al., } \\
2021 \text { [99] }\end{array}$ & 151 & $\mathrm{BC}$ & $\begin{array}{l}\text { Thirty CSF samples were analyzed with NGS and } \\
121 \text { with mFAST-SeqS } \\
\text { Sensitivity of NGS: } 8 / 30(26.7 \%) \\
\text { Sensitivity of mFAST-SeqS: } 112 / 121(92.6 \%) \\
\text { Aneuploidy was found in } 24 \text { patients using mFAST-SeqS } \\
\text { only and was correlated with worse prognosis }\end{array}$ \\
\hline $\begin{array}{l}\text { Ballester et al., } \\
\quad 2018 \text { [100] }\end{array}$ & 7 & Melanoma & $\begin{array}{l}\text { Thirty percent of patients with a negative CSF cytology } \\
\text { showed a CSF-ctDNA positivity } \\
\text { Droplet digital PCR }\end{array}$ \\
\hline
\end{tabular}

NSCLC: non-small-cell lung cancer; CSF: cerebrospinal fluid; PCR: polymerase chain reaction; ctDNA: circulating tumor DNA; BM: brain metastases; LM: leptomeningeal metastases; EGFR: epidermal growth factor receptor; PIK3CA: phosphatidylinositol-4,5-bisphosphate 3-kinase catalytic subunit alpha; HER2: human epidermal growth factor receptor 2; MPL: myeloproliferative leukemia; CDKN2A: cyclindependent kinase inhibitor 2A; TKI: tyrosine kinase inhibitor; ALK: anaplastic lymphoma kinase; MET: mesenchymal-epithelial transition factor; SNVs: single nucleotide variants; NGS: next-generation sequencing; iPFS: intracranial PFS; RB: retinoblastoma gene; HR: hormone receptor; ESR1: estrogen receptor type 1;mFAST-SeqS: modified Fast Aneuploidy Screening Test-Sequencing System.

Unfortunately, there is a paucity of studies comparing the accuracy of CTCs and ctDNA in both blood and CSF of patients with LM. It is unknown whether CTCs or ctDNA are superior for defining the genetic profile, as well as the spatial and temporal heterogeneity of tumors. However, the combination of CTCs and ctDNA may provide comprehensive information in terms of heterogeneity of tumor cells and prognosis. In this regard, Nevel et al. reported that patients with $\geq 50 \mathrm{CTCs} / 3 \mathrm{~mL}$ had an increased risk of death in comparison with that of those with $<50 \mathrm{CTCs} / 3 \mathrm{~mL}$, as well as that increased ctDNA concentrations were correlated with an increased risk of death [75]. Major concerns arise from the evidence that not all ctDNA may be tumor derived, and it could be too early to state that increased ctDNA concentrations in CSF could predict OS. The mutational status of LM may also impact survival. Zheng et al. reported that intracranial progression-free survival (iPFS) in patients with LM from NSCLC was higher in those harboring the EGFR 
exon 19 deletion (11.9 months) than in those with EGFR exon 21 L858 mutation (2.8 months). Moreover, the median iPFS was longer in patients with EGFR T790-positive CSF genotyping (15.6 months) than in those without T790 mutation (7.0 months). The concomitant presence of CD42 (2.8 months) and CDKN2A mutations (2.5 months) confers a shorter iPFS (11.6 and 9.6 months, respectively) than that of patients with negative CSF-ctDNA. Lastly, some resistant mutations, such as EGFR C795 mutation, MET dysregulation, co-occurrence of TP53 and RB1 mutations and loss of T790 mutation in CSF-ctDNA, were correlated with shorter survival in patients who progressed with LM after treatment with osimertinib [97]. Overall, the integration of the CSF liquid biopsy in the diagnostic flowchart may lead to several advantages in the management of LM, including diagnosis of LM in case of negative or "atypical" CSF cytology, monitoring of tumor response following targeted therapy or immunotherapy, early detection of LM recurrence and development of resistant mutations, early identification of subgroups of patients with a higher risk of LM recurrence and correlation of LM burden with survival. However, these attractive goals may only be achieved after collection and analysis of larger datasets of CSF liquid biopsy; thus, the rarity of LM requires a cooperative approach to make CTC and ctDNA data available to a larger community of basic and clinical researchers.

A new frontier in CSF liquid biopsy is proteomics. Smalley et al. collected 45 consecutive CSF samples from 16 patients with LM from melanoma: CSF was analyzed by mass spectrometry and incubated with melanoma cells, and RNA sequencing was performed. The mass spectrometry analysis revealed that the CSF of most LM was significantly enriched for pathways involved in innate immunity, protease and IGF-mediated signaling. Furthermore, RNA sequencing showed a significant activation of the PI3K/AKT pathway, integrin, TNFR2 and TGF- $\beta$, as well as B-cell activation and oxidative stress that were correlated with leptomeningeal progression, development of resistance to BRAF inhibitors and poor survival [101].

\section{Targeting LM with Systemic and Intrathecal Approaches}

Surgery may be useful to relieve increased intracranial pressure with the placement of ventriculo-peritoneal shunts. Ommaya reservoirs may also serve for the administration of intrathecal therapies. Different techniques of radiotherapy (RT) may be considered for the treatment of LM. In this regard, focal RT, such as involved field or SRS, may be delivered in selected patients with circumscribed and symptomatic lesions or with CSF flow obstructions for palliation or improvement of the distribution of intrathecal drugs. Wholebrain radiotherapy (WBRT) has been investigated in unfit patients with poor performance status in LM from different solid tumors and reported a modest benefit in neurological symptoms and pain control $[102,103]$. More aggressive approaches with craniospinal irradiation (CSI), using either conventional RT [104,105] or proton therapy [106], have been investigated with the aim to control the disease of the whole neuroaxis, but limited data on efficacy are available thus far. Overall, CSI is not typically considered the standard of care. Targeted therapy, immunotherapy and intrathecal therapy in selected patients may represent an optimal treatment for LM according to the molecular subtypes (Figure 4). 


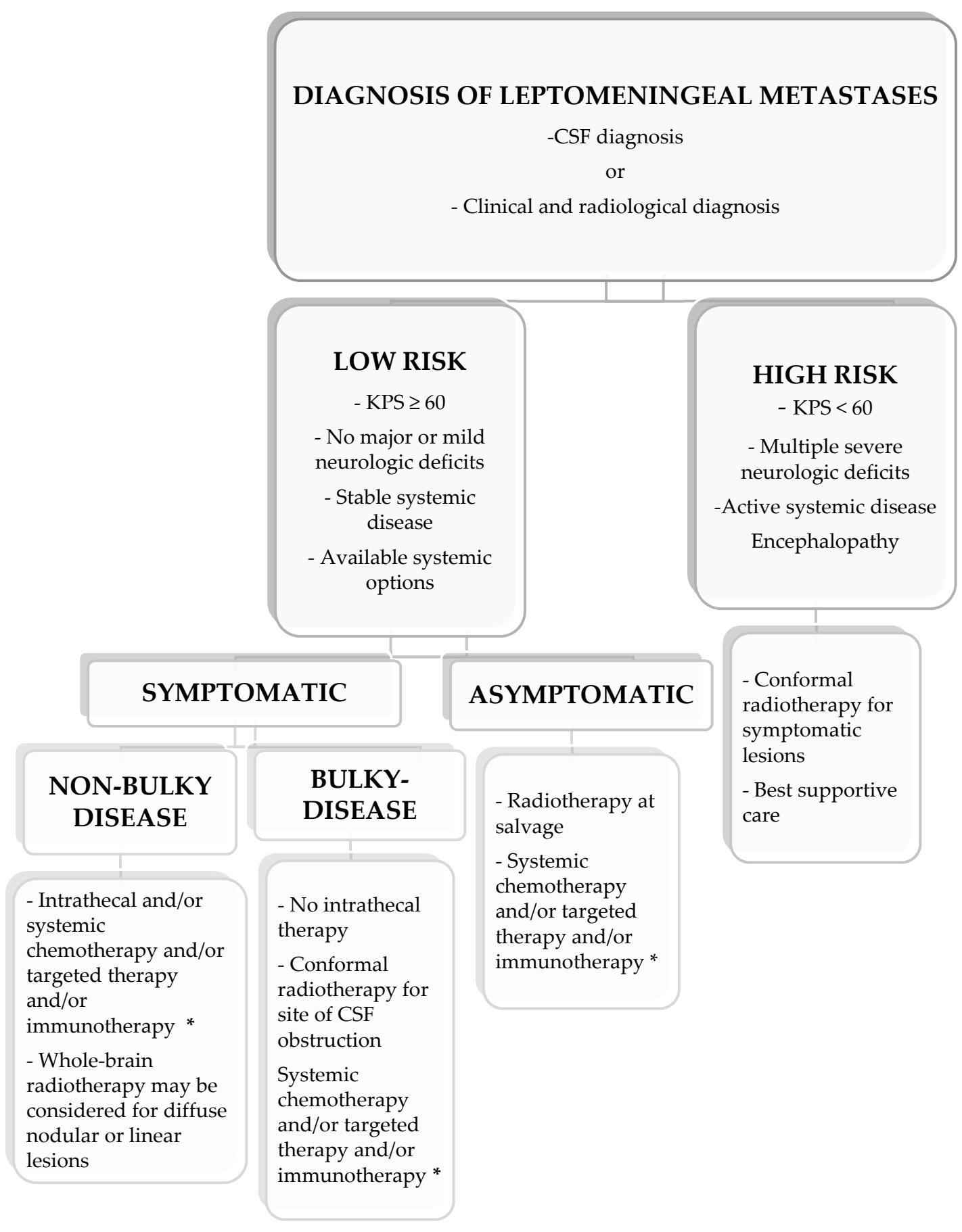

Figure 4. Treatment decision algorithm for leptomeningeal metastases. * Based on druggable mutations or PD-L1 expression.

\subsection{LM from EGFR-Mutated NSCLC}

LM occur more frequently in EGFR-mutated $(9.4 \%)$ compared with EGFR wild-type NSCLC $(1.7 \%)$ with a median OS of 13.3 months $[107,108]$. The first-generation TKIs have limited penetration into the CSF (1-3\%). The intensification of gefitinib or erlotinib using a "pulsatile" regimen has been proposed to increase the CSF concentrations with a median OS ranging from 3.5 to 12 months [109-113]. The second-generation TKI afatinib was evaluated in a prospective trial on 11 patients with LM pretreated with first-generation TKI. Five patients harbored an exon 19 deletion, three harbored a p.L858R point mutation, and three harbored an uncommon exon 18 mutation. A radiological response was achieved in $27.3 \%$ of patients, of whom two out of three harbored uncommon EGFR mutations, with a 
median PFS of 2.0 months and OS of 3.8 months [114]. A CNS recurrence following firstand second-generation TKIs occurs in $40 \%$ of patients due to the limited ability to cross the BBB and the development of resistant mechanisms. In this regard, the third-generation TKI osimertinib has shown a higher penetration through the BBB (CSF level 7.51 and $25.2 \mathrm{nmol} / \mathrm{L}$ when administered at $160 \mathrm{mg} /$ day and $300 \mathrm{mg}$ bid, respectively) and now is considered the first-line therapy in LM from EGFR-mutated NSCLC based on the results of several studies [115-123], regardless of T790 mutation status [121] (Table 4). The studies reported an intracranial response rate of 20-62\%, a median PFS of 7.2-17.2 months, a median OS of 11-18 months and a rapid neurological improvement in the majority of patients [118], as well as a clearance of CSF from neoplastic cells in 28\% [117]. Interestingly, osimertinib also displayed significant activity in patients harboring uncommon EGFR aberrations, including Leu858Arg [116] and S768I [122], and 750_758del, I759S and T751_I759delinsS mutations [123]. A preplanned analysis of the phase 3 FLAURA study investigated osimertinib in comparison with first-generation TKIs as un upfront treatment in metastatic Exon19 deleted/L858R EGFR-mutated NSCLC, showed that four out of five patients had a complete radiological response of LM. Together, these data suggest that osimertinib should be considered as the preferred initial treatment when feasible [124]. As pemetrexed has displayed some activity to control LM [125], the FLAURA2 trial is now investigating the efficacy of the association of osimertinib and pemetrexed in both BM and LM (NCT04035486) [126]. Another treatment option under investigation is the combination of bevacizumab and TKIs. A case report of LM from NSCLC treated with erlotinib and bevacizumab reported a neurological improvement and stabilization of disease lasting 18 months [127]. Osimertinib was investigated also in association with bevacizumab in a patient with LM displaying a durable clinical and radiological response of 10 months [128], and an ongoing trial is now addressing this combined treatment in LM (NCT04425681, NCT04148898) (Table 5).

Table 4. Studies on LM from NSCLC.

\begin{tabular}{|c|c|c|c|c|}
\hline Study & Type of Study & No. of Patients & Treatment & Results \\
\hline \multicolumn{5}{|c|}{ EGFR TKIs } \\
\hline $\begin{array}{l}\text { Grommes et al., } \\
2011 \text { [109] }\end{array}$ & Retrospective & 9 & $\begin{array}{l}\text { Pulsatile high-dose } \\
\text { erlotinib (1500 mg weekly) }\end{array}$ & $\begin{array}{l}\text { Radiological response in } \\
6 / 9 \text { patients }(66.7 \%) \\
\text { Median OS: } 12 \text { months }\end{array}$ \\
\hline Lee et al., 2013 [110] & Retrospective & 25 & $\begin{array}{l}\text { Arm 1: gefitinib } \\
250 \mathrm{mg} \text { /day } \\
\text { Arm 2: erlotinib } \\
150 \mathrm{mg} \text { /day }\end{array}$ & $\begin{array}{l}\text { Clearance of CSF cytology in } \\
10 / 25 \text { patients }(40 \%) \\
\text { Erlotinib led to CSF cytology } \\
\text { conversion in } 64.3 \% \text { of patients, } \\
\text { while only in } 9.1 \% \text { following } \\
\text { gefitinib }\end{array}$ \\
\hline $\begin{array}{l}\text { Yang et al., } \\
2015 \text { [111] }\end{array}$ & Retrospective & 6 & $\begin{array}{l}\text { Pemetrexed } 500 \mathrm{mg} / \mathrm{m}^{2} \\
\text { day } 1 \text {; cisplatin } 30 \mathrm{mg} \text { day } \\
\text { 1-2; erlotinib } 150 \mathrm{mg} \text { day } \\
3-21\end{array}$ & $\begin{array}{l}\text { Response rate: CR } 1 / 6(16.6 \%) ; \text { PR } \\
\text { 2/6 (33.3\%); SD } 2 / 6(33.3 \%) \\
\text { Median OS: } 9 \text { months }\end{array}$ \\
\hline $\begin{array}{l}\text { Kawamura et al., } \\
2015 \text { [112] }\end{array}$ & Retrospective & 35 & $\begin{array}{l}\text { Arm 1: high-dose erlotinib } \\
\text { (200-600 mg/day every } \\
\text { 2-4 days) } \\
\text { Arm 2: standard dose } \\
\text { erlotinib ( } 150 \mathrm{mg} / \text { day) }\end{array}$ & $\begin{array}{l}\text { High-dose erlotinib: radiological } \\
\text { response in } 3 / 10 \text { patients }(30 \%) \text {, } \\
\text { neurological improvement in } \\
6 / 12 \text { patients }(50 \%) \\
\text { Median OS: high-dose group: } \\
6.2 \text { months } \\
\text { Standard dose group: } 5.9 \text { months }\end{array}$ \\
\hline
\end{tabular}


Table 4. Cont.

\begin{tabular}{|c|c|c|c|c|}
\hline Study & Type of Study & No. of Patients & Treatment & Results \\
\hline $\begin{array}{l}\text { Jackman et al., } \\
2015 \text { [113] }\end{array}$ & Phase I & 7 & $\begin{array}{l}2 \text { weeks of high-dose of } \\
\text { gefitinib } \\
\text { ( } 750-1000 \mathrm{mg} / \text { day) and } \\
2 \text { weeks of } 500 \mathrm{mg} / \text { day }\end{array}$ & $\begin{array}{l}\text { Median OS: } 3.5 \text { months } \\
\text { Median PFS: } 2.3 \text { months } \\
\text { CSF cytology clearance in } \\
1 / 7 \text { patients }(14.3 \%) \\
\text { Neurological improvement in } \\
4 / 7 \text { patients }(57.1 \%)\end{array}$ \\
\hline $\begin{array}{l}\text { Liao et al., } \\
2015 \text { [129] }\end{array}$ & Retrospective & 75 & $\begin{array}{l}\text { Arm A: Gefitinib + CT } \\
\text { Arm B: Erlotinib + CT } \\
\text { Arm C: Afatinib + CT } \\
\text { Regimen details not } \\
\text { available }\end{array}$ & $\begin{array}{l}\text { The association of TKI plus } \\
\text { chemotherapy is correlated with } \\
\text { prolonged survival in both } \\
\text { univariate and multivariate } \\
\text { analysis }\end{array}$ \\
\hline $\begin{array}{l}\text { Tamiya et al., } \\
2017 \text { [114] }\end{array}$ & Prospective & 11 & Afatinib $40 \mathrm{mg} / \mathrm{m}^{2}$ daily & $\begin{array}{l}\text { Median CSF penetration: } 2.45 \% \\
\text { Median CSF concentration: } \\
1.4 \mathrm{ng} / \mathrm{mL}(2.9 \mathrm{nM}) \\
\text { Radiological response: } 27.3 \% \\
\text { Median PFS: } 2 \text { months } \\
\text { Median OS: } 3.8 \text { months }\end{array}$ \\
\hline $\begin{array}{l}\text { Yang et al., } \\
2017 \text { [115] }\end{array}$ & Phase I & 32 & Osimertinib 160 mg daily & $\begin{array}{l}20 / 23 \text { patients }(86.9 \%) \text { had } \\
\text { neurological improvement } \\
23 / 32(72 \%) \text { had radiological } \\
\text { response }\end{array}$ \\
\hline $\begin{array}{l}\text { Nanjo et al., } \\
2018 \text { [116] }\end{array}$ & Prospective & $\begin{array}{c}13 \\
\text { (3 definitive LM } \\
\text { and } 8 \text { possible } \\
\text { LM) }\end{array}$ & Osimertinib 80 mg daily & $\begin{array}{l}\text { CSF penetration: } 2.5 \% \\
\text { Median PFS: } 7.2 \text { months }\end{array}$ \\
\hline $\begin{array}{l}\text { Yang et al., } \\
2020 \text { [117] }\end{array}$ & Prospective & 41 & Osimertinib 160 mg daily & $\begin{array}{l}\text { ORR } 62 \% \\
\text { Median OS } 15.2 \text { months }\end{array}$ \\
\hline $\begin{array}{l}\text { Saboundji et al., } \\
\quad 2018 \text { [118] }\end{array}$ & Retrospective & 20 & Osimertinib $80 \mathrm{mg}$ daily & $\begin{array}{l}\text { 100\% of patients experienced } \\
\text { neurological improvement } \\
\text { Median PFS: } 17.2 \text { months } \\
\text { Median OS: } 18 \text { months }\end{array}$ \\
\hline $\begin{array}{l}\text { Ahn et al., } \\
2020 \text { [119] }\end{array}$ & Retrospective & 22 & Osimertinib $80 \mathrm{mg}$ daily & $\begin{array}{l}\text { ORR 55\% } \\
\text { Median OS } 18.8 \text { months }\end{array}$ \\
\hline $\begin{array}{l}\text { Park et al., } \\
2020[120]\end{array}$ & Phase 2 & 40 & Osimertinib 160 mg daily & $\begin{array}{l}\text { ORR 55\% } \\
\text { Median PFS } 7.6 \text { months } \\
\text { Median OS } 16.9 \text { months }\end{array}$ \\
\hline Lee et al., 2020 [121] & Retrospective & $\begin{array}{l}351 \\
87 \text { with T790 } \\
\text { mutation }\end{array}$ & Osimertinib & $\begin{array}{l}\text { No difference in median OS } \\
\text { according to T790M mutational } \\
\text { status }(10.1 \text { months ( } 95 \% \text { CI } \\
4.3-15.8) \text { versus } 9.0 \text { months ( } 95 \% \\
\text { CI: } 6.8-11.21) \text { ) } \\
\text { Patients treated with osimertinib } \\
\text { had a superior OS of } 17.0 \text { months } \\
\text { (95\% CI } 15.1-18.9) \text { compared with } \\
\text { that of those not treated with } \\
\text { osimertinib who had a median OS } \\
\text { of } 5.5 \text { months }(95 \% \text { CI } 4.3-6.6) \text {, } \\
\text { regardless of T790M mutational } \\
\text { status }\end{array}$ \\
\hline
\end{tabular}


Table 4. Cont.

\begin{tabular}{|c|c|c|c|c|}
\hline Study & Type of Study & No. of Patients & Treatment & Results \\
\hline $\begin{array}{l}\text { Ahn et al., } \\
2016 \text { [130] }\end{array}$ & Prospective & $\begin{array}{c}29 \\
\text { (4 with LM) }\end{array}$ & AZD3759 & $\begin{array}{l}3 / 4 \text { patients }(75 \%) \text { had a } \\
\text { significant reduction of EGFR } \\
\text { expression } \\
1 / 4 \text { patients }(25 \%) \text { had a CSF } \\
\text { conversion in two consecutive } \\
\text { samples }\end{array}$ \\
\hline $\begin{array}{l}\text { Cho et al., } \\
2017 \text { [131] }\end{array}$ & Prospective & 18 & $\begin{array}{l}\text { Arm 1: AZD3759 } 200 \mathrm{mg} \\
\text { daily } \\
\text { Arm 2: AZD3759 } 300 \mathrm{mg} \\
\text { daily }\end{array}$ & $\begin{array}{l}5 / 18 \text { patients }(27.8 \%) \text { had a } \\
\text { radiological response, while } \\
9 / 18 \text { patients }(50 \%) \text { had a stable } \\
\text { disease }\end{array}$ \\
\hline Xu et al., 2020 [132] & Prospective & 3 & $\begin{array}{l}\text { erlotinib (150 mg/day) } \\
\text { plus nimotuzumab } \\
\left(200 \mathrm{mg} / \mathrm{m}^{2}\right) \text { weekly }\end{array}$ & $\begin{array}{l}\text { Rapid clinical response within } \\
6-8 \text { weeks from the start of } \\
\text { treatment } \\
2 / 3 \text { patients reported a } \\
\text { radiological response }\end{array}$ \\
\hline
\end{tabular}

\begin{tabular}{|c|c|c|c|c|}
\hline \multicolumn{5}{|c|}{ ALK inhibitors } \\
\hline $\begin{array}{l}\text { Costa et al., } \\
2011 \text { [133] }\end{array}$ & Case report & 1 & $\begin{array}{l}\text { WBRT plus crizotinib } \\
250 \mathrm{mg} \text { twice daily }\end{array}$ & PFS: 9 months \\
\hline $\begin{array}{l}\text { Ahn et al., } \\
2012[134]\end{array}$ & Case series & 2 & $\begin{array}{l}\text { Intrathecal MTX plus } \\
\text { crizotinib } 250 \mathrm{mg} \text { twice } \\
\text { daily }\end{array}$ & PFS 5 and 10 months, respectively \\
\hline $\begin{array}{l}\text { Arrondeau et al., } \\
\quad 2014 \text { [135] }\end{array}$ & Case report & 1 & Ceritinib 750 mg daily & PFS: 5.5 months \\
\hline $\begin{array}{l}\text { Dudnik et al., } \\
2015 \text { [136] }\end{array}$ & Case series & 3 & $\begin{array}{l}\text { WBRT plus ceritinib } \\
500 \mathrm{mg} / \text { daily }\end{array}$ & $\begin{array}{l}\text { PFS patient 1: } 18 \text { months; patient } 2 \\
\text { and } 3: 7 \text { months }\end{array}$ \\
\hline $\begin{array}{l}\text { Gainor et al., } \\
2015 \text { [137] }\end{array}$ & Case series & 4 & $\begin{array}{l}\text { Alectinib } 600 \mathrm{mg} \text { twice } \\
\text { daily }\end{array}$ & $\begin{array}{l}\text { Radiological and neurological } \\
\text { improvement in } 4 \text { / } 4 \text { patients }(75 \%)\end{array}$ \\
\hline Ou et al., 2015 [138] & Case report & 1 & $\begin{array}{l}\text { Alectinib } 600-750 \mathrm{mg} \text { twice } \\
\text { daily }\end{array}$ & $\begin{array}{l}\text { Long-lasting complete response } \\
\text { (15 months) }\end{array}$ \\
\hline $\begin{array}{l}\text { Gainor et al., } \\
2016 \text { [139] }\end{array}$ & Case series & 2 & $\begin{array}{l}\text { Alectinib } 900 \text { mg twice } \\
\text { daily }\end{array}$ & $\begin{array}{l}\text { Radiological and neurological } \\
\text { improvement for } 3.5 \text { and } 6 \text { months, } \\
\text { respectively }\end{array}$ \\
\hline $\begin{array}{l}\text { Gaye et al., } \\
2019 \text { [140] }\end{array}$ & Case report & 1 & $\begin{array}{l}\text { Brigatinib } 180 \mathrm{mg} \text { once } \\
\text { daily with a } 7 \text { day lead-in } \\
\text { period at } 90 \mathrm{mg}\end{array}$ & PFS 14 months \\
\hline $\begin{array}{l}\text { Pellerino et al., } \\
\quad 2019 \text { [141] }\end{array}$ & Case report & 1 & $\begin{array}{l}\text { Lorlatinib } 100 \mathrm{mg} \text { once } \\
\text { daily }\end{array}$ & $\begin{array}{l}\text { PFS } 12 \text { months } \\
\text { Complete radiological response }\end{array}$ \\
\hline $\begin{array}{l}\text { Frost et al., } \\
2020[142]\end{array}$ & Prospective & $\begin{array}{c}36 \mathrm{BM} \\
9 \mathrm{LM}\end{array}$ & Lorlatinib 100 mg daily & $\begin{array}{l}\text { Median duration of treatment: } \\
10.4 \text { months } \\
\text { PFS: } 8.0 \text { months } \\
\text { Intracranial response rate: } 54 \% \\
\text { Time to treatment failure: } \\
13.0 \text { months } \\
\text { Calculated } 12-, 18 \text { - and } 24 \text {-month } \\
\text { OS were } 65,54 \text { and } 47 \% \\
\text { TP53 mutations were associated } \\
\text { with a shorter PFS ( } 3.7 \text { versus } \\
10.8 \text { months), suggesting a role as } \\
\text { strong prognostic biomarker }\end{array}$ \\
\hline
\end{tabular}

ALK: anaplastic lymphoma kinase; LM: leptomeningeal metastases; EGFR: epidermal growth factor receptor; TKIs: tyrosine kinase inhibitors; PFS: progression-free survival; ORR: objective response rate; CR: complete response; PR: partial response; SD: stable disease; OS: overall survival; TKI: tyrosine kinase inhibitor; CSF: cerebrospinal fluid; BM: brain metastases; LM: leptomeningeal metastases. 
Table 5. Ongoing clinical trial on LM (from https: / clinicaltrials.gov, last update 1 March 2021).

\begin{tabular}{|c|c|c|c|c|}
\hline Study & $\begin{array}{l}\text { Number of } \\
\text { Patients }\end{array}$ & Primary Solid Tumor & Treatment & Primary Outcome Measure \\
\hline $\begin{array}{l}\text { NCT04356118 } \\
\text { Phase } 4\end{array}$ & 30 & NSCLC & $\begin{array}{l}\text { Recombinant human } \\
\text { endostatin }+ \text { intrathecal } \\
\text { MTX + targeted therapy } \\
\text { (EGFR TKIs or ALK } \\
\text { inhibitors) }\end{array}$ & $\begin{array}{c}\text { OS } \\
\text { Neurological PFS } \\
\text { Adverse events }\end{array}$ \\
\hline $\begin{array}{l}\text { NCT04356222 } \\
\text { Phase } 4\end{array}$ & 30 & NSCLC & $\begin{array}{l}\text { Durvalumab + intrathecal } \\
\text { MTX }\end{array}$ & $\begin{array}{c}\text { OS } \\
\text { Neurological PFS } \\
\text { Adverse events }\end{array}$ \\
\hline $\begin{array}{l}\text { NCT04315246 } \\
\text { Phase } 1 / 2\end{array}$ & 63 & $\begin{array}{l}\text { Ductal or lobular BC, } \\
\text { NSCLC, melanoma }\end{array}$ & $\begin{array}{l}\text { Intracerebroventricular } \\
\text { administration of } \\
\text { 177Lu-DTPA-omburtamab }\end{array}$ & $\begin{array}{l}\text { Incidence of AEs and SAEs } \\
\quad \text { (time frame: } 1 \text { year) }\end{array}$ \\
\hline $\begin{array}{l}\text { NCT03661424 } \\
\text { Phase I }\end{array}$ & 16 & HER2-positive BC & $\begin{array}{c}\text { Anti-CD3 x } \\
\text { Anti-HER2/Neu (HER2Bi) } \\
\text { Armed Activated T Cells } \\
\text { (BATs) }\end{array}$ & $\begin{array}{l}\text { Type, frequency, severity, } \\
\text { duration and timing of AEs } \\
\text { Number of patients who } \\
\text { achieved the } 80 \% \text { of the total } \\
\text { administrations of BATs }\end{array}$ \\
\hline $\begin{array}{l}\text { NCT04192981 } \\
\text { Phase } 1\end{array}$ & 36 & $\begin{array}{l}\text { Primary solid tumors } \\
\text { harboring PIK3CA } \\
\text { mutations }\end{array}$ & $\begin{array}{l}\text { GDC-0084 with or without } \\
\text { WBRT }\end{array}$ & $\begin{array}{l}\text { Primary: } \\
\text { MTD }\end{array}$ \\
\hline $\begin{array}{l}\text { NCT03974204 } \\
\text { Phase: NA }\end{array}$ & 74 & $\mathrm{BC}$ & - & $\begin{array}{c}\text { Proteomic profiles from CSF at } \\
\text { diagnosis } \\
\text { CSF cytology positivity at } \\
\text { diagnosis }\end{array}$ \\
\hline $\begin{array}{c}\text { NCT04729348 } \\
\text { Phase } 2 \\
\end{array}$ & 19 & Any solid tumors & $\begin{array}{l}\text { Pembrolizumab plus } \\
\text { Lenvatinib }\end{array}$ & Six-month OS \\
\hline $\begin{array}{l}\text { NCT04425681 } \\
\text { Phase } 2\end{array}$ & 20 & EGFR-mutated NSCLC & $\begin{array}{l}\text { Osimertinib + } \\
\text { bevacizumab }\end{array}$ & $\begin{array}{l}\text { ORR } \\
\text { PFS }\end{array}$ \\
\hline $\begin{array}{l}\text { NCT04148898 } \\
\text { Phase } 2\end{array}$ & 80 & EGFR-mutated NSCLC & $\begin{array}{c}\text { Arm 1: Osimertinib alone } \\
\text { Arm 2: Osimertinib + } \\
\text { bevacizumab }\end{array}$ & $\begin{array}{c}\text { Intracranial PFS } \\
\text { ORR }\end{array}$ \\
\hline $\begin{array}{l}\text { NCT04233021 } \\
\text { Phase } 2\end{array}$ & 113 & EGFR-mutated NSCLC & Osimertinib alone & ORR \\
\hline $\begin{array}{l}\text { NCT03696030 } \\
\text { Phase } 1\end{array}$ & 39 & HER2-positive BC & $\begin{array}{c}\text { Intraventricular } \\
\text { administration of } \\
\text { autologous HER2-CAR T } \\
\text { Cells }\end{array}$ & $\begin{array}{l}\text { DLT } \\
\text { AEs }\end{array}$ \\
\hline $\begin{array}{l}\text { NCT03719768 } \\
\text { Phase } 1 b\end{array}$ & 23 & Any solid tumors & Avelumab + WBRT & Safety and DLT \\
\hline $\begin{array}{l}\text { NCT04588545 } \\
\text { Phase } 1 / 2\end{array}$ & 39 & HER2-positive BC & $\begin{array}{l}\text { Focal RT or WBRT + } \\
\text { intrathecal } \\
\text { trastuzumab/pertuzumab }\end{array}$ & $\begin{array}{l}\text { MTD } \\
\text { OS }\end{array}$ \\
\hline $\begin{array}{l}\text { NCT02422641 } \\
\text { Phase } 2\end{array}$ & 16 & Any subtypes of BC & $\begin{array}{c}\text { Intravenous high-dose } \\
\text { MTX }\end{array}$ & 12-week OS \\
\hline $\begin{array}{l}\text { NCT03613181 } \\
\text { Phase } 3\end{array}$ & 150 & HER2-negative BC & $\begin{array}{c}\text { ANG1005 versus } \\
\text { Physician's Best Choice }\end{array}$ & OS \\
\hline $\begin{array}{l}\text { NCT03501979 } \\
\text { Phase } 2\end{array}$ & 30 & HER2-positive BC & $\begin{array}{c}\text { Tucatinib + Trastuzumab + } \\
\text { Capecitabine }\end{array}$ & OS \\
\hline
\end{tabular}


Table 5. Cont.

\begin{tabular}{cccc}
\hline Study & $\begin{array}{c}\text { Number of } \\
\text { Patients }\end{array}$ & Primary Solid Tumor & Treatment \\
\hline NCT04420598 & 39 & Cohort 5: \\
Phase 2 & HER2-positive or & Trastuzumab deruxtecan \\
& HER2-low expressing & \\
\hline
\end{tabular}

NSCLC: non-small-cell lung cancer; MTX: methotrexate; EGFR TKIs: epidermal growth factor receptor tyrosine kinase inhibitors; ALK: anaplastic lymphoma kinase; OS: overall survival; PFS: progression-free survival; ORR: objective response rate; BC: breast cancer; AEs: adverse events; SAEs: severe adverse events; PK: pharmacokinetics; dOR: duration of objective response; HER2: human epidermal growth factor receptor 2; BATS: bispecific activated T cells; NA: not applicable; HR: hormonal receptor; TNBC: triple-negative breast cancer; QoL: quality of life; CAR: chimeric antigen receptor; WBC: white blood cells; CTCs: circulating tumor cells; DLT: dose-limiting toxicity; RT: radiotherapy; WBRT: whole-brain radiotherapy; MTD: maximum tolerated dose.

AZD3759 is a novel compound primarily designed to cross the BBB that has displayed a remarkable ability to penetrate into the CSF, as well as significant efficacy in three out of four patients with LM in a phase I trial [130]. Cho et al. reported a radiological response in $5 / 18$ patients $(27.8 \%)$ and a stable disease in $9 / 18(50 \%)$ following two different doses of AZD3759 (200 and $300 \mathrm{mg}$, respectively) without significant difference in tolerability [131]. A newer generation of TKIs have been investigated: nimotuzumab led to a significant radiological response in two out of three LM [132], while tesevatinib showed activity in disease control of advanced NSCLC, and a clinical trial on BM and LM has been completed in January 2020, and the results are awaited (NCT02616393).

\subsection{LM from ALK-Rearranged NSCLC}

ALK mutations are rare and can be found in approximately $3-7 \%$ of patients with NSCLC. ALK-rearranged NSCLC recurs in approximately in 35-40\% of patients with BM and in $5 \%$ of patients with LM after a median time of 9 months from the diagnosis of the primary tumor [143].

ALK inhibitors have changed the natural history and prognosis of advanced NSCLC, including patients with BM, but data on LM are limited to case reports. Although the first-generation ALK inhibitor crizotinib has a poor penetration through the BBB (CSF level $0.14 \mathrm{nmol} / \mathrm{L}$ when administered at $250 \mathrm{mg} /$ day), some cases have been reported with a prolonged PFS (6-10 months) when crizotinib is given following WBRT or concurrent with intrathecal methotrexate (MTX) in LM $[133,134]$. The second-generation ALK inhibitor ceritinib displayed some activity (PFS 5-18 months) in LM when combined with traditional chemotherapy or WBRT after failure of crizotinib $[135,136]$. Three different ASCEND trials have shown a significant intracranial response rate following ceritinib in patients with BM, heavily pretreated with chemotherapy and crizotinib; however, no details regarding LM response have been reported [144-146]. Alectinib is a second-generation ALK inhibitor with a higher CSF penetration $(2.69 \mathrm{nmol} / \mathrm{L})$ that became the preferred first-line therapy in ALKrearranged patients according to the phase 3 ALEX study, where alectinib was compared with crizotinib [147]. To date, a total of six patients with LM received alectinib with a daily dose ranging from 600 to $900 \mathrm{mg}$, reporting a durable neurological and radiological improvement and a median PFS of 3.5-15 months [137-139]. The third-generation ALKinhibitors brigatinib and lorlatinib have displayed significant intracranial activity compared to the older generations of ALK-inhibitors [148-151]; however, the activity on LM has not been fully investigated. To date, two different case reports displayed a prolonged PFS in LM following brigatinib and lorlatinib, respectively [140,141]. In an interim analysis of the results from the CROWN study among patients with $\mathrm{BM}$, those who received lorlatinib achieved an intracranial objective response rate (iORR) of $82 \%$, while those treated with crizotinib had an iORR of only $23 \%$. Notably, $71 \%$ of the patients who received lorlatinib had an intracranial complete response, suggesting major intracranial activity of lorlatinib compared with other ALK-TKIs [151]. Recently, Frost et al. reported the results of the German early access program on lorlatinib in 36 patients with symptomatic BM and 9 LM 
after the failure of first- and second-generation ALK inhibitors: an intracranial response rate of $54 \%$, a median duration of treatment of 10.4 months and a median PFS of 8.0 months were reported. Overall, this is the first real-life experience showing the efficacy of lorlatinib in heavily pretreated patients with BM and LM and also in patients harboring resistance mutations (e.g., G1202R and G2032R mutations) [142].

\subsection{LM from Breast Cancer}

$B C$ expresses different molecular markers, including estrogen receptors (ER), progesterone receptors (PR) and HER2, leading to molecular subtypes with a different risk of developing CNS recurrences and survival; thus, the molecular profile should be obtained to tailor treatments [152]. In fact, patients with triple-negative BC (TNBC) show the highest incidence of LM (36\%), with a shorter time to development of LM and OS [153,154], while LM occur approximately in 14\% of patients with ER/PR-negative and HER2-positive BC and in $2.2 \%$ of patients with luminal A (low-grade and ER-positive) BC [155].

\subsubsection{HER2-Positive LM from Breast Cancer}

Trastuzumab has been demonstrated to prolong OS (15.2 versus 9.9 months) and delay the onset of BM in HER2-positive BC, suggesting a preventive role by blocking the entry of tumor cells into the CNS [156]; however, CNS is the first site of relapse following trastuzumab due to the poor ability to cross the BBB $[11,157,158]$. Therefore, the efficacy of trastuzumab was evaluated when administered intrathecally and compared with intrathecal MTX/thioTEPA or WBRT: prolonged LM control of more than 10 months in four patients treated with intrathecal trastuzumab was reported, as well as a one-year OS of 54\% compared with 10\% following intrathecal MTX/thioTEPA and 19\% following WBRT [159]. Recently, Zagouri et al. conducted a meta-analysis on intrathecal trastuzumab in patients with LM from HER2-positive BC, reporting a median PFS and OS of 5.2 and 13.2 months, respectively, as well as a CSF clearance in $56 \%$ of patients and a radiological improvement or stabilization in nearly $71 \%$ [160]. As some old studies reported a limited palliative activity of standard intrathecal chemotherapy (MTX, liposomal ara-C and ThioTEPA) [161-165], intrathecal trastuzumab may be more effective in terms of LM control and outcome when compared with historical cohorts, but further prospective trials are needed. The association of trastuzumab, pertuzumab and docetaxel is considered the standard first-line treatment in HER2-enriched advanced BC, according to the CLEOPATRA trial; however, data on activity in BM or LM are lacking, as the enrollment of patients with CNS recurrences were not allowed [166]. A clinical trial of intrathecal pertuzumab/trastuzumab in association with focal RT or WBRT in LM is underway (NCT04588545) (Table 5).

The antibody-drug conjugate trastuzumab emtansine (TDM-1) represents a further advancement to treat metastatic HER2-positive BC with significant activity in both asymptomatic and symptomatic BM [167-169], but little is known regarding its efficacy in LM. To date, one case report reported a clinical and radiological response lasting $>3$ months after the association of TDM-1 with WBRT in a patient with HER2-positive LM [170]. The evolution of TDM- 1 is represented by trastuzumab deruxtecan, which is now under investigation in a distinct cohort focused on HER2-enriched LM of the DEBBRAH trial (NCT04420598) (Table 5).

New HER2-TKIs, such as lapatinib, neratinib and, in particular, tucatinib, have improved better penetration into the CNS and displayed an impact in intracranial disease control in BM of patients pretreated with trastuzumab, especially when administered with capecitabine [171-173]. Freedman et al. enrolled three patients with LM pretreated with lapatinib and reported one partial response after seven cycles of capecitabine plus neratinib and one stable disease and one progressive disease after four cycles, respectively [171]. An Italian cohort of heavily pretreated LM (median number of adjuvant therapies of 3 ) received capecitabine plus neratinib as part of a compassionate program: the median PFS and OS were 4.0 and 10 months, respectively. Moreover, a neurological improvement was reported in two out of seven patients (28.6\%), while in three out of seven patients $(42.8 \%)$, 
a neurological stabilization was achieved, lasting for a median time of 5 months. The best radiological response was stable disease in four out of seven patients (57.1\%), while no complete or partial responses were achieved [174]. To date, no data are available regarding the activity of tucatinib in LM: a phase 2 trial has already enrolled 30 patients with LM who received trastuzumab plus capecitabine and tucatinib (NCT03501979) (Table 5).

In a separate study of non-HER2-directed therapy, Lu et al. reported an intracranial response in 19/34 HER2-positive patients (68\%) affected by LM who received bevacizumab in combination with etoposide and cisplatin (BEEP regimen), with a median OS of 13.6 months [175].

\subsubsection{ER-Positive LM from Breast Cancer}

A small number of case reports have described a benefit from hormonal therapy (HT), which consists of tamoxifen or fulvestrant in pre-perimenopausal women, or a luteinizing hormone releasing hormone (LHRH) agonist for post-menopausal women [176-179]. The introduction in clinical practice of CDK4/6 inhibitors, which inhibit cyclin D1 pathways and arrest the proliferation of ER-positive BC cells, in combination with estrogen therapy or an LHRH agonist, had a minor impact on intracranial disease control in BM [180-182], but the activity in LM has not been investigated thus far. New treatment strategies are urgently needed: in this regard, the estrogen receptor degraders (SERDs) aim to block the ER pathway, and some clinical trials on metastatic BC are ongoing (NCT02248090, NCT2338349).

\subsubsection{LM from Triple-Negative BC}

The standard of care for advanced TNBC is represented by platinum-based chemotherapy, such as carboplatin, which has demonstrated better tolerability compared with docetaxel, regardless of BRCA (breast cancer susceptibility genes 1 or 2) status [152]. The mutations of BRCA1/2 genes impair the ability of the poly adenosine diphosphate ribose polymerase (PARP) enzymes to repair the DNA double-strand breaks that lead to the apoptosis of tumor cells. Different PARP inhibitors, including iniparib, olaparib, talazoparib and veliparib, demonstrated some activity in metastatic TNBC, including in patients with asymptomatic BM $[183,184]$. To date, two case reports have displayed some activity of olaparib in LM from BRCA1/2 mutated TNBC. Bengham et al. described a dramatic response of LM of the spinal cord and the skull base after 4 months from the start of olaparib, with a duration of 12 months. Clinical and radiological improvement was also confirmed by the clearance of CSF from neoplastic cells, as well as a reduction of the CSF level of CA-125 [185]. A similar result was reported by Exman et al. in a patient with BRCA2 mutation achieving a complete neurological and radiological response following olaparib after 19 months of therapy [186]. Further investigations are warranted allowing the enrollment of patients with LM in trials that aim to address the efficacy of PARP inhibitors in TNBC harboring BRCA1/2 aberrations.

When druggable mutations are not expressed on tumor cells, immunotherapy may represent an option in TNBC. However, a recent trial on atezolizumab on advanced and metastatic TNBC did not show a significant benefit in patients with BM [187]. Despite these results, several clinical trials are now evaluating the role of immune checkpoint inhibitors (ICIs), such as nivolumab (NCT03807765), pembrolizumab (NCT03449238) and atezolizumab (NCT03483012), in combination with SRS in BM from TNBC. Recently, a single-arm, phase 2 study of pembrolizumab in 20 patients with LM from solid tumors (17 BC, 2 NSCLC and 1 ovarian cancer) showed promising results. Twelve out of twenty patients $(60 \%)$ met the primary endpoint of three-month OS $(60 \%)$ with a manageable toxicity ( $40 \%$ of grade 3 adverse events). Further analyses are ongoing to identify subgroups of patients that may benefit from anti PDL-1 treatment [188].

Modifying the structure of traditional chemotherapy and linking it to peptide vector or pegylation is another strategy to increase the penetration through the BBB. The taxane agent ANG1005 consists of three paclitaxel molecules covalently linked to angiopep-2, 
which is able to cross the BBB by the LRP1 transport system. Kumthekar et al. conducted a phase II study on intravenously ANG1005 in 72 patients with CNS recurrences from BC, including 28 with LM, and reported a clinical benefit in $77 \%$ of patients and an intracranial response rate in $15 \%$. Of note, $79 \%$ of patients with LM had disease control with a median OS of 8.0 months [189]. These encouraging results have led to other randomized trials to validate this compound in recurrent BM (NCT02048059) and LM (NCT03613181).

\subsection{LM from Melanoma}

About $50 \%$ of advanced melanoma has mutations in position 600 (v600) of the serine/threonine kinase BRAF with some evidence of increased risk of progression in the CNS [190]. Although targeted therapy can reach adequate levels in the CSF, there is wide interpatient variability of vemurafenib concentrations, reflecting the different permeability of BTB. The combination of local therapy, including surgery and RT, can impact the BTB permeability with the highest levels of vemurafenib achieved following SRS [191]. Few case reports reported a clinical and radiological response after BRAF inhibitors or MEK inhibitors, with prompt neurological symptom relief and CSF cytological remission [189,192-197]. Arasaratnam et al. reported an advantage of BRAF inhibitors in a cohort of 11 patients with LM from melanoma [190]. Interestingly, patients who continue to receive BRAF inhibitors beyond progression, as well as patients who received treatment at the time of diagnosis of LM, had benefited from BRAF inhibitors with a median OS of 7.2 months. It is not clear whether the association of BRAF inhibitors and MEK inhibitors may improve the efficacy in LM as reported in BM and extracranial sites [198]; however, initial reports regarding the combination of targeted therapy and immunotherapy with RT are emerging. In this regard, 28 patients with LM were treated with targeted therapy $(n=5)$, traditional chemotherapy $(n=1)$, anti-PD-1 alone $(n=17)$ or in combination with a BRAF inhibitor $(n=4)$, achieving a median OS of 7.1 months for the patients receiving systemic therapy combined with RT and 3.2 months for those not receiving RT [199].

Immune checkpoint inhibitors (ICIs) have drastically changed the natural history and survival of metastatic melanoma patients, including those with BM, while the knowledge regarding the activity on LM mainly derives from few case reports, using WBRT in combination with ipilimumab [200] or anti-PD-1 [197], with durable neurological improvement. Cohort $\mathrm{C}$ of the $\mathrm{ABC}$ phase II study enrolled four patients with LM who received nivolumab as a single agent, but none of them responded, achieving a poor median OS of 5.1 months [201]. Intrathecal immunotherapy has also been considered in LM from melanoma, with some concerns regarding the possibility of inducing dramatic inflammation in the CNS and, though rare, severe neurological adverse events. The cytokine interleukin (IL)-2 was delivered intrathecally in a cohort of patients with LM from melanoma: a median OS of 9.1 months was achieved with one-year, two-year and five-year OS of 36, 26 and $13 \%$, respectively. However, severe adverse events were reported, including increased intracranial pressure, that required an intensive care observation [202]. When intrathecal IL-2 therapy fails, other innovative strategies have been investigated, such as educated cytotoxic T lymphocytes (cyt-T cells) after the interaction with autologous dendritic cells charged with different melanoma antigens (melanoma-associated antigens tyrosinase, Melan-A/MART, gp100/Pmel17). One patient only received cyt-T cells by Ommaya reservoir showing increased CSF TNF- $\alpha$, IFN- $\gamma$ and IL- 6 concentrations as well as an OS > 18 months from the diagnosis of LM [203]. One other patient received cyt-T cells intrathecally after the failure of IL-2: the patient died after 5 months from the start of treatment for systemic progressive disease, but LM remained stable [204]. The safety of nivolumab was investigated intrathecally via an intraventricular reservoir in association with an intravenous route in 15 patients with evidence of LM on MRI and/or CSF cytology from heavily pretreated metastatic melanoma (anti-PD-1: 11 patients; BRAF/MEK inhibitors: 9 patients; traditional chemotherapy: 2 patients; intrathecal IL-2: 4 patients; other therapies: 2 patients). Two patients received intrathecal nivolumab at $5 \mathrm{mg}$, 3 patients at $10 \mathrm{mg}$ and 10 patients at $20 \mathrm{mg}$. No grade $4-5$ adverse events were reported with in- 
trathecal or intravenous nivolumab. With a median follow-up of 18.7 weeks, the median OS was of 46.1 weeks (0.1-83.3). Clinical response data and translational research endpoints, including changes in CSF cytokines and cfDNA, are still under investigation [205].

\section{Novel Techniques to Improve Drug Delivery across the BBB}

Novel techniques are under investigation to overcome the limits posed by BBB and improve the penetration of drugs into the CNS. In this regard, cranial implantable ultrasound emitters, when combined with microbubbles intravenously, transiently disrupts the BBB, and the penetration of larger and polar molecules into the CNS is more feasible. The BBB opening is reversible and lasts several hours after the ultrasound application. However, the thick human skull represents a barrier for the penetration of ultrasounds; thus, the implanting of an ultrasound emitter into a window on the patients' skull is mandatory to overcome the intrinsic resistance of the skull [206] and could result in further discomfort for patients with symptomatic LM. Idbaih et al. have reported the successful opening of the BBB in 52 of 65 sonication sessions in 19 patients with recurrent glioblastomas using an implantable ultrasound emitter in combination with carboplatin [207]. Several clinical trials are now evaluating the ability to open the BBB by cranial ultrasound emitters, but they are reserved for circumscribed high-grade gliomas or brain metastases and not for a diffuse disease with multilevel involvement of the neuroaxis, such as LM. Moreover, the impact of ultrasounds to disrupt the BTB and the CSF barriers, as well as the ability to improve the CSF concentrations of targeted therapy and/or immunotherapy in LM, is unknown. An additional problem is the rapid turnover of CSF, which leads to fluctuating concentrations and shorter half-life of compounds in the CSF, as well as a limited exposure of floating tumor cells to antineoplastic agents. Gene therapy has been suggested to solve the problem of larger compound delivery through the BBB in one shot administration. Adeno-associated viral (AAV) vectors, particularly serotype 9, can deliver exogenous genes, such as the gene for trastuzumab, to the entire neuroaxis after a single intrathecal administration, leading to a durable and stable expression of the transgene product in both CNS and CSF. Rothwell et al. reported in an orthotopic Rag1-/- murine xenograft model of HER2-positive BM from BC that a single prophylactic intrathecal administration of an AAV9-trastuzumab vector increased the median OS (124 versus 50 days), attenuated brain tumor growth and preserved both the HER2 antigen specificity and the natural killer cell-associated mechanism of action of trastuzumab. The authors stated that they intend to move AAV9-trastuzumab toward a human clinical trial after the completion of preclinical studies, including safety and toxicology experiments in large animal models. The next step will be to assess the safety, efficacy and pharmacokinetics of AAV9-trastuzumab in women with documented CNS lesions from HER2-enriched BC. Of note, as AAV transgene expression has been reported to persist for years in primates and humans, this approach has been suggested as a potential additional part of the adjuvant therapy with the aim to prevent CNS recurrences for patients with early diagnosis of HER2-positive BC [208].

\section{Conclusions}

Leptomeningeal space remains a sanctuary site, and little is known about the microenvironment of LM. The peculiar adaption to compartments with different metabolic features, such as the brain parenchyma and circulating CSF, selects unique intracellular survival pathways during proliferation and clonal selection, leading to growth of tumor cells in two distinct anatomical compartments [209]. Therefore, the mechanisms underlying the invasion of the CNS as well as the interaction of tumor cells with either the brain parenchyma or leptomeningeal space may be regulated by distinct pathways based on molecular subgroups that need to be further investigated. Overall, targeted therapy and immunotherapy may be active on cells in specific contexts, but a better understanding of molecular pathways that regulate the penetration of different compounds through the $\mathrm{BBB} / \mathrm{BTB}$ interface is limited. 
The current knowledge of efficacy of newer intrathecal and targeted or immunotherapy approaches primarily derives from case reports or analyses of small subgroups of patients in clinical trials. Thus far, these new treatment options impact a small percentage of patients with LM. An urgent need is to design clinical trials on LM for longitudinal CSF, blood and tissue collection at diagnosis and during treatment to monitor clinical and radiological response, obtain pharmacokinetic information and identify markers of response and resistance. In this regard, different combinations of treatments, such as EGFR TKIs with antiangiogenic agents and intrathecal chemotherapy or antiangiogenic therapy with anti-PD-L1 in LM from NSLCLC, as well as intrathecal chemotherapy or ant-PD-L1 with RT in LM from BC, are under investigation in clinical trials (Table 5). However, due to the rarity of LM, a multicenter cooperative effort is crucial to achieve a significant sample size in order to derive robust results regarding the efficacy of treatments.

Author Contributions: Conceptualization: A.P. and R.S.; data curation: A.P., P.K.B. and R.R.; writing-original draft preparation: A.P.; writing—review and editing: A.P., P.K.B., R.S. and R.R.; supervision: R.S. All authors have read and agreed to the published version of the manuscript.

Funding: This research received no external funding.

Acknowledgments: In this section you can acknowledge any support given which is not covered by the author contribution or funding sections. This may include administrative and technical support, or donations in kind (e.g., materials used for experiments).

Conflicts of Interest: A.P. declares no conflict of interest. P.B. declares the following financial disclosure: Angiochem, Genentech-Roche, Lilly, Tesaro, Voyager Therapeutics, ElevateBio, Pfizer (Array), Pfizer, SK Life Sciences and Dantari; received grant/research support (to Massachusetts General Hospital) from Merck, Mirati, BMS and Lilly; honoraria from Merck, Pfizer, Genentech-Roche and Lilly. R.R. declares the following financial disclosure: UCB, Mundipharma, Bayer and Novocure. R.S declares the following financial disclosure: AstraZeneca, Merck and Orbus e Agios Therapeutics.

\section{References}

1. Le Rhun, E.; Galanis, E. Leptomeningeal metastases of solid cancer. Curr. Opin. Neurol. 2016, 29, 797-805. [CrossRef]

2. Le Rhun, E.; Taillibert, S.; Chamberlain, M.C. Carcinomatous meningitis: Leptomeningeal metastases in solid tumors. Surg. Neurol. Int. 2013, 4, S265-S288. [CrossRef]

3. Glitza, I.C.; Smalley, K.S.M.; Brastianos, P.K.; Davies, M.A.; McCutcheon, I.; Liu, J.K.C.; Ahmed, K.A.; Arrington, J.A.; Evernden, B.R.; Smalley, I.; et al. Leptomeningeal disease in melanoma patients: An update to treatment, challenges, and future directions. Pigment Cell Melanoma Res. 2020, 33, 527-541. [CrossRef]

4. Cheng, H.; Perez-Soler, R. Leptomeningeal metastases in non-small-cell lung cancer. Lancet Oncol. 2018, 19, e43-e55. [CrossRef]

5. Franzoi, M.A.; Hortobagyi, G.N. Leptomeningeal carcinomatosis in patients with breast cancer. Crit. Rev. Oncol. Hematol. 2019, 135, 85-94. [CrossRef]

6. O'Brown, N.M.; Pfau, S.J.; Gu, C. Bridging barriers: A comparative look at the blood-brain barrier across organisms. Genes Dev. 2018, 32, 466-478. [CrossRef]

7. Ayloo, S.; Gu, C. Transcytosis at the blood-brain barrier. Curr. Opin. Neurobiol. 2019, 57, 32-38. [CrossRef]

8. Obermeier, B.; Daneman, R.; Ransohoff, R.M. Development, maintenance and disruption of the blood-brain barrier. Nat. Med. 2013, 19, 1584-1596. [CrossRef]

9. Pardridge, W.M. CSF, blood-brain barrier, and brain drug delivery. Expert Opin. Drug Deliv. 2016, 13, 963-975. [CrossRef]

10. Liu, Y.; Cao, X. Characteristics and Significance of the Pre-metastatic Niche. Cancer Cell 2016, 30, 668-681. [CrossRef]

11. Olson, E.M.; Abdel-Rasoul, M.; Maly, J.; Wu, C.S.; Lin, N.U.; Shapiro, C.L. Incidence and risk of central nervous system metastases as site of first recurrence in patients with HER2-positive breast cancer treated with adjuvant trastuzumab. Ann. Oncol. 2013, 24, 1526-1533. [CrossRef]

12. Patil, T.; Smith, D.E.; Bunn, P.A.; Aisner, D.L.; Le, A.T.; Hancock, M.; Purcell, W.T.; Bowles, D.W.; Camidge, D.R.; Doebele, R.C. The Incidence of Brain Metastases in Stage IV ROS1-Rearranged Non-Small Cell Lung Cancer and Rate of Central Nervous System Progression on Crizotinib. J. Thorac. Oncol. 2018, 13, 1717-1726. [CrossRef]

13. Schinkel, A.H.; Smit, J.J.; van Tellingen, O.; Beijnen, J.H.; Wagenaar, E.; van Deemter, L.; Mol, C.A.; van der Valk, M.A.; RobanusMaandag, E.C.; te Riele, H.P.; et al. Disruption of the mouse mdr1a P-glycoprotein gene leads to a deficiency in the blood-brain barrier and to increased sensitivity to drugs. Cell 1994, 77, 491-502. [CrossRef]

14. Sanchez-Covarrubias, L.; Slosky, L.M.; Thompson, B.J.; Davis, T.P.; Ronaldson, P.T. Transporters at CNS barrier sites: Obstacles or opportunities for drug delivery? Curr. Pharm. Des. 2014, 20, 1422-1449. [CrossRef] 
15. Wijaya, J.; Fukuda, Y.; Schuetz, J.D. Obstacles to Brain Tumor Therapy: Key ABC Transporters. Int. J. Mol. Sci. 2017, 18, 2544. [CrossRef]

16. Soffietti, R.; Ahluwalia, M.; Lin, N.; Rudà, R. Management of brain metastases according to molecular subtypes. Nat. Rev. Neurol. 2020, 16, 557-574. [CrossRef]

17. Lyle, L.T.; Lockman, P.R.; Adkins, C.E.; Mohammad, A.S.; Sechrest, E.; Hua, E.; Palmieri, D.; Liewehr, D.J.; Steinberg, S.M.; Kloc, W.; et al. Alterations in Pericyte Subpopulations Are Associated with Elevated Blood-Tumor Barrier Permeability in Experimental Brain Metastasis of Breast Cancer. Clin. Cancer Res. 2016, 22, 5287-5299. [CrossRef]

18. Tiwary, S.; Morales, J.E.; Kwiatkowski, S.C.; Lang, F.F.; Rao, G.; McCarty, J.H. Metastatic Brain Tumors Disrupt the Blood-Brain Barrier and Alter Lipid Metabolism by Inhibiting Expression of the Endothelial Cell Fatty Acid Transporter Mfsd2a. Sci. Rep. 2018, 8, 8267. [CrossRef]

19. Gril, B.; Paranjape, A.N.; Woditschka, S.; Hua, E.; Dolan, E.L.; Hanson, J.; Wu, X.; Kloc, W.; Izycka-Swieszewska, E.; Duchnowska, R.; et al. Reactive astrocytic S1P3 signaling modulates the blood-tumor barrier in brain metastases. Nat. Commun. $2018,9,2705$. [CrossRef]

20. Yonemori, K.; Tsuta, K.; Ono, M.; Shimizu, C.; Hirakawa, A.; Hasegawa, T.; Hatanaka, Y.; Narita, Y.; Shibui, S.; Fujiwara, Y. Disruption of the blood brain barrier by brain metastases of triple-negative and basal-type breast cancer but not HER2/neupositive breast cancer. Cancer 2010, 116, 302-308. [CrossRef]

21. Taskar, K.S.; Rudraraju, V.; Mittapalli, R.K.; Samala, R.; Thorsheim, H.R.; Lockman, J.; Gril, B.; Hua, E.; Palmieri, D.; Polli, J.W.; et al. Lapatinib distribution in HER2 overexpressing experimental brain metastases of breast cancer. Pharm. Res. 2012, 29, 770-781. [CrossRef] [PubMed]

22. Zou, H.Y.; Friboulet, L.; Kodack, D.P.; Engstrom, L.D.; Li, Q.; West, M.; Tang, R.W.; Wang, H.; Tsaparikos, K.; Wang, J.; et al. PF-06463922, an ALK/ROS1 Inhibitor, Overcomes Resistance to First and Second Generation ALK Inhibitors in Preclinical Models. Cancer Cell 2015, 28, 70-81. [CrossRef] [PubMed]

23. Henry, M.N.; Chen, Y.; McFadden, C.D.; Simedrea, F.C.; Foster, P.J. In-vivo longitudinal MRI study: An assessment of melanoma brain metastases in a clinically relevant mouse model. Melanoma Res. 2015, 25, 127-137. [CrossRef]

24. Kienast, Y.; von Baumgarten, L.; Fuhrmann, M.; Klinkert, W.E.; Goldbrunner, R.; Herms, J.; Winkler, F. Real-time imaging reveals the single steps of brain metastasis formation. Nat. Med. 2010, 16, 116-122. [CrossRef] [PubMed]

25. Murrell, D.H.; Hamilton, A.M.; Mallett, C.L.; van Gorkum, R.; Chambers, A.F.; Foster, P.J. Understanding Heterogeneity and Permeability of Brain Metastases in Murine Models of HER2-Positive Breast Cancer Through Magnetic Resonance Imaging: Implications for Detection and Therapy. Transl. Oncol. 2015, 8, 176-184. [CrossRef] [PubMed]

26. Arvanitis, C.D.; Askoxylakis, V.; Guo, Y.; Datta, M.; Kloepper, J.; Ferraro, G.B.; Bernabeu, M.O.; Fukumura, D.; McDannold, N.; Jain, R.K. Mechanisms of enhanced drug delivery in brain metastases with focused ultrasound-induced blood-tumor barrier disruption. Proc. Natl. Acad. Sci. USA 2018, 115, E8717-E8726. [CrossRef]

27. Kodack, D.P.; Chung, E.; Yamashita, H.; Incio, J.; Duyverman, A.M.; Song, Y.; Farrar, C.T.; Huang, Y.; Ager, E.; Kamoun, W.; et al. Combined targeting of HER2 and VEGFR2 for effective treatment of HER2-amplified breast cancer brain metastases. Proc. Natl. Acad. Sci. USA 2012, 109, E3119-E3127. [CrossRef]

28. Wyatt, E.A.; Davis, M.E. Method of establishing breast cancer brain metastases affects brain uptake and efficacy of targeted, therapeutic nanoparticles. Bioeng. Transl. Med. 2018, 4, 30-37. [CrossRef]

29. Morikawa, A.; Peereboom, D.M.; Thorsheim, H.R.; Samala, R.; Balyan, R.; Murphy, C.G.; Lockman, P.R.; Simmons, A.; Weil, R.J.; Tabar, V.; et al. Capecitabine and lapatinib uptake in surgically resected brain metastases from metastatic breast cancer patients: A prospective study. Neuro Oncol. 2015, 17, 289-295. [CrossRef]

30. Saleem, A.; Searle, G.E.; Kenny, L.M.; Huiban, M.; Kozlowski, K.; Waldman, A.D.; Woodley, L.; Palmieri, C.; Lowdell, C.; Kaneko, T.; et al. Lapatinib access into normal brain and brain metastases in patients with Her-2 overexpressing breast cancer. EJNMMI Res. 2015, 5, 1-10. [CrossRef]

31. Lewis Phillips, G.D.; Nishimura, M.C.; Lacap, J.A.; Kharbanda, S.; Mai, E.; Tien, J.; Malesky, K.; Williams, S.P.; Marik, J.; Phillips, H.S. Trastuzumab uptake and its relation to efficacy in an animal model of HER2-positive breast cancer brain metastasis. Breast Cancer Res. Treat. 2017, 164, 581-591. [CrossRef] [PubMed]

32. Askoxylakis, V.; Ferraro, G.B.; Kodack, D.P.; Badeaux, M.; Shankaraiah, R.C.; Seano, G.; Kloepper, J.; Vardam, T.; Martin, J.D.; Naxerova, K.; et al. Preclinical Efficacy of Ado-trastuzumab Emtansine in the Brain Microenvironment. J. Natl. Cancer Inst. 2015, 108, djv313. [CrossRef] [PubMed]

33. Kummar, S.; Rubinstein, L.; Kinders, R.; Parchment, R.E.; Gutierrez, M.E.; Murgo, A.J.; Ji, J.; Mroczkowski, B.; Pickeral, O.K.; Simpson, M.; et al. Phase 0 clinical trials: Conceptions and misconceptions. Cancer J. 2008, 14, 133-137. [CrossRef]

34. Pellerino, A.; Bertero, L.; Rudà, R.; Soffietti, R. Neoplastic meningitis in solid tumors: From diagnosis to personalized treatments. Ther. Adv. Neurol. Disord. 2018, 11, 1756286418759618. [CrossRef]

35. Chang, P.C.; Fischbein, N.J.; McCalmont, T.H.; Kashani-Sabet, M.; Zettersten, E.M.; Liu, A.Y.; Weissman, J.L. Perineural spread of malignant melanoma of the head and neck: Clinical and imaging features. AJNR Am. J. Neuroradiol. 2004, 25, 5-11. [CrossRef] [PubMed]

36. Ahn, J.H.; Lee, S.H.; Kim, S.; Joo, J.; Yoo, H.; Lee, S.H.; Shin, S.H.; Gwak, H.S. Risk for leptomeningeal seeding after resection for brain metastases: Implication of tumor location with mode of resection. J. Neurosurg. 2012, 116, 984-993. [CrossRef] 
37. Mahajan, A.; Ahmed, S.; McAleer, M.F.; Weinberg, J.S.; Li, J.; Brown, P.; Settle, S.; Prabhu, S.S.; Lang, F.F.; Levine, N.; et al. Post-operative stereotactic radiosurgery versus observation for completely resected brain metastases: A single-centre, randomised, controlled, phase 3 trial. Lancet Oncol. 2017, 18, 1040-1048. [CrossRef]

38. Foreman, P.M.; Jackson, B.E.; Singh, K.P.; Romeo, A.K.; Guthrie, B.L.; Fisher, W.S.; Riley, K.O.; Markert, J.M.; Willey, C.D.; Bredel, M.; et al. Postoperative radiosurgery for the treatment of metastatic brain tumor: Evaluation of local failure and leptomeningeal disease. J. Clin. Neurosci. 2018, 49, 48-55. [CrossRef]

39. Boire, A.; Zou, Y.; Shieh, J.; Macalinao, D.G.; Pentsova, E.; Massagué, J. Complement Component 3 Adapts the Cerebrospinal Fluid for Leptomeningeal Metastasis. Cell 2017, 168, 1101-1113. [CrossRef]

40. Conrad, C.; Dorzweiler, K.; Miller, M.A.; Lauffenburger, D.A.; Strik, H.; Bartsch, J.W. Profiling of metalloprotease activities in cerebrospinal fluids of patients with neoplastic meningitis. Fluids Barriers CNS 2017, 14, 22. [CrossRef]

41. Chi, Y.; Remsik, J.; Kiseliovas, V.; Derderian, C.; Sener, U.; Alghader, M.; Saadeh, F.; Nikishina, K.; Bale, T.; Iacobuzio-Donahue, C.; et al. Cancer cells deploy lipocalin-2 to collect limiting iron in leptomeningeal metastasis. Science 2020, 369, 276-282. [CrossRef]

42. Remsik, J.; Chi, Y.; Tong, X.; Sener, U.; Derderian, C.; Park, A.; Saadeh, F.; Bale, T.; Boire, A. Leptomeningeal metastatic cells adopt two phenotypic states. Cancer Rep. 2020, e1236. [CrossRef] [PubMed]

43. Palmieri, D.; Bronder, J.L.; Herring, J.M.; Yoneda, T.; Weil, R.J.; Stark, A.M.; Kurek, R.; Vega-Valle, E.; Feigenbaum, L.; Halverson, D.; et al. Her-2 overexpression increases the metastatic outgrowth of breast cancer cells in the brain. Cancer Res. 2007, 67, 4190-4198. [CrossRef]

44. Allen, J.E.; Patel, A.S.; Prabhu, V.V.; Dicker, D.T.; Sheehan, J.M.; Glantz, M.J.; El-Deiry, W.S. COX-2 drives metastatic breast cells from brain lesions into the cerebrospinal fluid and systemic circulation. Cancer Res. 2014, 74, 2385-2390. [CrossRef]

45. Dankner, M.; Caron, M.; Al-Saadi, T.; Yu, W.; Ouellet, V.; Ezzeddine, R.; Maritan, S.M.; Annis, M.G.; Le, P.U.; Nadaf, J.; et al. Invasive growth associated with Cold-Inducible RNA-Binding Protein expression drives recurrence of surgically resected brain metastases. Neuro Oncol. 2021, noab002. [CrossRef] [PubMed]

46. Nanjo, S.; Arai, S.; Wang, W.; Takeuchi, S.; Yamada, T.; Hata, A.; Katakami, N.; Okada, Y.; Yano, S. MET Copy Number Gain Is Associated with Gefitinib Resistance in Leptomeningeal Carcinomatosis of EGFR-mutant Lung Cancer. Mol. Cancer Ther. 2017, 16, 506-515. [CrossRef] [PubMed]

47. Balak, M.N.; Gong, Y.; Riely, G.J.; Somwar, R.; Li, A.R.; Zakowski, M.F.; Chiang, A.; Yang, G.; Ouerfelli, O.; Kris, M.G.; et al. Novel D761Y and common secondary T790M mutations in epidermal growth factor receptor-mutant lung adenocarcinomas with acquired resistance to kinase inhibitors. Clin. Cancer Res. 2006, 12, 6494-6501. [CrossRef] [PubMed]

48. Fan, Y.; Hu, M.; Zhu, X.; Wang, M.; Xu, Y.; Lv, X.; Xu, H.; Ding, J.; Ye, X.; Fang, L.; et al. Exploration of the underlying mechanisms of leptomeningeal metastasis in NSCLC patients through NGS of cerebrospinal fluid. J. Thorac. Oncol. 2017, 12, S271. [CrossRef]

49. Jiang, B.Y.; Yangsi, L.; Chuai, S.; Zhang, Z.; Yang, J.J.; Zhong, W.; Zhou, Q.; Wu, I.L. NGS to reveal heterogeneity between cerebrospinal fluid and plasma ctDNA among non-small cell lung cancer patients with leptomeningeal carcinomatosis. Proc. Am. Soc. Clin. Oncol. 2017, 35, 9022. [CrossRef]

50. Oxnard, G.R.; Arcila, M.E.; Sima, C.S.; Riely, G.J.; Chmielecki, J.; Kris, M.G.; Pao, W.; Ladanyi, M.; Miller, V.A. Acquired resistance to EGFR tyrosine kinase inhibitors in EGFR-mutant lung cancer: Distinct natural history of patients with tumors harboring the T790M mutation. Clin. Cancer Res. 2011, 17, 1616-1622. [CrossRef]

51. Brastianos, P.K.; Carter, S.L.; Santagata, S.; Cahill, D.P.; Taylor-Weiner, A.; Jones, R.T.; Van Allen, E.M.; Lawrence, M.S.; Horowitz, P.M.; Cibulskis, K.; et al. Genomic Characterization of Brain Metastases Reveals Branched Evolution and Potential Therapeutic Targets. Cancer Discov. 2015, 5, 1164-1177. [CrossRef] [PubMed]

52. Shih, D.J.H.; Nayyar, N.; Bihun, I.; Dagogo-Jack, I.; Gill, C.M.; Aquilanti, E.; Bertalan, M.; Kaplan, A.; D’Andrea, M.R.; Chukwueke, U.; et al. Genomic characterization of human brain metastases identifies drivers of metastatic lung adenocarcinoma. Nat. Genet. 2020, 52, 371-377. [CrossRef]

53. Hohensee, I.; Lamszus, K.; Riethdorf, S.; Meyer-Staeckling, S.; Glatzel, M.; Matschke, J.; Witzel, I.; Westphal, M.; Brandt, B.; Müller, V.; et al. Frequent genetic alterations in EGFR- and HER2-driven pathways in breast cancer brain metastases. Am. J. Pathol. 2013, 183, 83-95. [CrossRef]

54. Wikman, H.; Lamszus, K.; Detels, N.; Uslar, L.; Wrage, M.; Benner, C.; Hohensee, I.; Ylstra, B.; Eylmann, K.; Zapatka, M.; et al. Relevance of PTEN loss in brain metastasis formation in breast cancer patients. Breast Cancer Res. 2012, 14, R49. [CrossRef] [PubMed]

55. Le Rhun, E.; Weller, M.; Brandsma, D.; Van den Bent, M.; de Azambuja, E.; Henriksson, R.; Boulanger, T.; Peters, S.; Watts, C.; Wick, W.; et al. EANO-ESMO Clinical Practice Guidelines for diagnosis, treatment and follow-up of patients with leptomeningeal metastasis from solid tumours. Ann. Oncol. 2017, 28, iv84-iv99. [CrossRef]

56. Le Rhun, E.; Devos, P.; Weller, J.; Seystahl, K.; Mo, F.; Compter, A.; Berghoff, A.S.; Jongen, J.L.M.; Wolpert, F.; Rudà, R.; et al. Prognostic validation and clinical implications of the EANO ESMO classification of leptomeningeal metastasis from solid tumors. Neuro Oncol. 2020, noaa298. [CrossRef] [PubMed]

57. Chamberlain, M.; Junck, L.; Brandsma, D.; Soffietti, R.; Rudà, R.; Raizer, J.; Boogerd, W.; Taillibert, S.; Groves, M.D.; Le Rhun, E.; et al. Leptomeningeal metastases: A RANO proposal for response criteria. Neuro Oncol. 2017, 19, 484-492. [CrossRef] [PubMed] 
58. Le Rhun, E.; Devos, P.; Boulanger, T.; Smits, M.; Brandsma, D.; Rudà, R.; Furtner, J.; Hempel, J.M.; Postma, T.J.; Roth, P.; et al. The RANO Leptomeningeal Metastasis Group proposal to assess response to treatment: Lack of feasibility and clinical utility and a revised proposal. Neuro Oncol. 2019, 21, 648-658. [CrossRef]

59. Prabhu, R.S.; Turner, B.E.; Asher, A.L.; Marcrom, S.R.; Fiveash, J.B.; Foreman, P.M.; Press, R.H.; Patel, K.R.; Curran, W.J.; Breen, W.G.; et al. A multi-institutional analysis of presentation and outcomes for leptomeningeal disease recurrence after surgical resection and radiosurgery for brain metastases. Neuro Oncol. 2019, 21, 1049-1059. [CrossRef]

60. Turner, B.E.; Prabhu, R.S.; Burri, S.H.; Brown, P.D.; Pollom, E.L.; Milano, M.T.; Weiss, S.E.; Iv, M.; Fischbein, N.; Soliman, H.; et al. Nodular Leptomeningeal Disease-A Distinct Pattern of Recurrence After Postresection Stereotactic Radiosurgery for Brain Metastases: A Multi-institutional Study of Interobserver Reliability. Int. J. Radiat. Oncol. Biol. Phys. 2020, 106, 579-586. [CrossRef] [PubMed]

61. Nguyen, T.K.; Sahgal, A.; Detsky, J.; Atenafu, E.G.; Myrehaug, S.; Tseng, C.L.; Husain, Z.; Heyn, C.; Maralani, P.; Ruschin, M.; et al. Predictors of leptomeningeal disease following hypofractionated stereotactic radiotherapy for intact and resected brain metastases. Neuro Oncol. 2020, 22, 84-93. [CrossRef]

62. Morikawa, A.; Jordan, L.; Rozner, R.; Patil, S.; Boire, A.; Pentsova, E.; Seidman, A.D. Characteristics and Outcomes of Patients With Breast Cancer With Leptomeningeal Metastasis. Clin. Breast Cancer 2017, 17, 23-28. [CrossRef]

63. Subirá, D.; Serrano, C.; Castañón, S.; Gonzalo, R.; Illán, J.; Pardo, J.; Martínez-García, M.; Millastre, E.; Aparisi, F.; Navarro, M.; et al. Role of flow cytometry immunophenotyping in the diagnosis of leptomeningeal carcinomatosis. Neuro Oncol. 2012, 14, 43-52. [CrossRef]

64. Nayak, L.; Fleisher, M.; Gonzalez-Espinoza, R.; Lin, O.; Panageas, K.; Reiner, A.; Liu, C.M.; Deangelis, L.M.; Omuro, A. Rare cell capture technology for the diagnosis of leptomeningeal metastasis in solid tumors. Neurology 2013, 80, 1598-1605. [CrossRef] [PubMed]

65. Subirá, D.; Simó, M.; Illán, J.; Serrano, C.; Castañón, S.; Gonzalo, R.; Granizo, J.J.; Martínez-García, M.; Navarro, M.; Pardo, J.; et al. Diagnostic and prognostic significance of flow cytometry immunophenotyping in patients with leptomeningeal carcinomatosis. Clin. Exp. Metastasis 2015, 32, 383-391. [CrossRef] [PubMed]

66. Lee, J.S.; Melisko, M.E.; Magbanua, M.J.; Kablanian, A.T.; Scott, J.H.; Rugo, H.S.; Park, J.W. Detection of cerebrospinal fluid tumor cells and its clinical relevance in leptomeningeal metastasis of breast cancer. Breast Cancer Res. Treat. 2015, 154, 339-349. [CrossRef] [PubMed]

67. Tu, Q.; Wu, X.; Le Rhun, E.; Blonski, M.; Wittwer, B.; Taillandier, L.; De Carvalho Bittencourt, M.; Faure, G.C. CellSearch technology applied to the detection and quantification of tumor cells in CSF of patients with lung cancer leptomeningeal metastasis. Lung Cancer 2015, 90, 352-357. [CrossRef]

68. Milojkovic Kerklaan, B.; Pluim, D.; Bol, M.; Hofland, I.; Westerga, J.; van Tinteren, H.; Beijnen, J.H.; Boogerd, W.; Schellens, J.H.; Brandsma, D. EpCAM-based flow cytometry in cerebrospinal fluid greatly improves diagnostic accuracy of leptomeningeal metastases from epithelial tumors. Neuro Oncol. 2016, 18, 855-862. [CrossRef]

69. Glantz, M.J.; Cole, B.F.; Glantz, L.K.; Cobb, J.; Mills, P.; Lekos, A.; Walters, B.C.; Recht, L.D. Cerebrospinal fluid cytology in patients with cancer: Minimizing false-negative results. Cancer 1998, 82, 733-739. [CrossRef]

70. van Bussel, M.T.J.; Pluim, D.; Bol, M.; Beijnen, J.H.; Schellens, J.H.M.; Brandsma, D. EpCAM-based assays for epithelial tumor cell detection in cerebrospinal fluid. J. Neurooncol. 2018, 137, 1-10. [CrossRef]

71. Campoli, M.R.; Chang, C.C.; Kageshita, T.; Wang, X.; McCarthy, J.B.; Ferrone, S. Human high molecular weight-melanomaassociated antigen (HMW-MAA): A melanoma cell surface chondroitin sulfate proteoglycan (MSCP) with biological and clinical significance. Crit. Rev. Immunol. 2004, 24, 267-296. [CrossRef]

72. Le Rhun, E.; Tu, Q.; De Carvalho Bittencourt, M.; Farre, I.; Mortier, L.; Cai, H.; Kohler, C.; Faure, G.C. Detection and quantification of CSF malignant cells by the CellSearch technology in patients with melanoma leptomeningeal metastasis. Med. Oncol. 2013, 30, 538. [CrossRef] [PubMed]

73. Hyun, K.A.; Koo, G.B.; Han, H.; Sohn, J.; Choi, W.; Kim, S.I.; Jung, H.I.; Kim, Y.S. Epithelial-to-mesenchymal transition leads to loss of EpCAM and different physical properties in circulating tumor cells from metastatic breast cancer. Oncotarget 2016, 7 , 24677-24687. [CrossRef] [PubMed]

74. Patel, A.S.; Allen, J.E.; Dicker, D.T.; Peters, K.L.; Sheehan, J.M.; Glantz, M.J.; El-Deiry, W.S. Identification and enumeration of circulating tumor cells in the cerebrospinal fluid of breast cancer patients with central nervous system metastases. Oncotarget 2011, 2, 752-760. [CrossRef] [PubMed]

75. Nevel, K.S.; DiStefano, N.; Lin, X.; Skakodub, A.; Ogilvie, S.Q.; Reiner, A.S.; Pentsova, E.; Boire, A. A retrospective, quantitative assessment of disease burden in patients with leptomeningeal metastases from non-small-cell lung cancer. Neuro Oncol. 2020, 22, 675-683. [CrossRef]

76. Jiang, B.Y.; Li, Y.S.; Guo, W.B.; Zhang, X.C.; Chen, Z.H.; Su, J.; Zhong, W.Z.; Yang, X.N.; Yang, J.J.; Shao, Y.; et al. Detection of Driver and Resistance Mutations in Leptomeningeal Metastases of NSCLC by Next-Generation Sequencing of Cerebrospinal Fluid Circulating Tumor Cells. Clin. Cancer Res. 2017, 23, 5480-5488. [CrossRef] [PubMed]

77. Magbanua, M.J.; Melisko, M.; Roy, R.; Sosa, E.V.; Hauranieh, L.; Kablanian, A.; Eisenbud, L.E.; Ryazantsev, A.; Au, A.; Scott, J.H.; et al. Molecular profiling of tumor cells in cerebrospinal fluid and matched primary tumors from metastatic breast cancer patients with leptomeningeal carcinomatosis. Cancer Res. 2013, 73, 7134-7143. [CrossRef] 
78. Li, X.; Zhang, Y.; Ding, J.; Wang, M.; Li, N.; Yang, H.; Wang, K.; Wang, D.; Ping Lin, P.; Li, M.; et al. Clinical significance of detecting CSF-derived tumor cells in breast cancer patients with leptomeningeal metastasis. Oncotarget 2018, 9, $2705-2714$. [CrossRef]

79. Cordone, I.; Masi, S.; Summa, V.; Carosi, M.; Vidiri, A.; Fabi, A.; Pasquale, A.; Conti, L.; Rosito, I.; Carapella, C.M.; et al. Overexpression of syndecan-1, MUC-1, and putative stem cell markers in breast cancer leptomeningeal metastasis: A cerebrospinal fluid flow cytometry study. Breast Cancer Res. 2017, 19, 46. [CrossRef]

80. Le Rhun, E.; Massin, F.; Tu, Q.; Bonneterre, J.; Bittencourt Mde, C.; Faure, G.C. Development of a new method for identification and quantification in cerebrospinal fluid of malignant cells from breast carcinoma leptomeningeal metastasis. BMC Clin. Pathol. 2012, 12, 21. [CrossRef]

81. Acosta, M.; Pereira, J.; Arroz, M. Screening of carcinoma metastasis by flow cytometry: A study of 238 cases. Cytom. B Clin. Cytom. 2016, 90, 289-294. [CrossRef]

82. Ma, C.; Lv, Y.; Jiang, R.; Li, J.; Wang, B.; Sun, L. Novel method for the detection and quantification of malignant cells in the CSF of patients with leptomeningeal metastasis of lung cancer. Oncol. Lett. 2016, 11, 619-623. [CrossRef]

83. Lin, X.; Fleisher, M.; Rosenblum, M.; Lin, O.; Boire, A.; Briggs, S.; Bensman, Y.; Hurtado, B.; Shagabayeva, L.; DeAngelis, L.M.; et al. Cerebrospinal fluid circulating tumor cells: A novel tool to diagnose leptomeningeal metastases from epithelial tumors. Neuro Oncol. 2017, 19, 1248-1254. [CrossRef] [PubMed]

84. van Bussel, M.T.J.; Pluim, D.; Milojkovic Kerklaan, B.; Bol, M.; Sikorska, K.; Linders, D.T.C.; van den Broek, D.; Beijnen, J.H.; Schellens, J.H.M.; Brandsma, D. Circulating epithelial tumor cell analysis in CSF in patients with leptomeningeal metastases. Neurology 2020, 94, e521-e528. [CrossRef]

85. Malani, R.; Fleisher, M.; Kumthekar, P.; Lin, X.; Omuro, A.; Groves, M.D.; Lin, N.U.; Melisko, M.; Lassman, A.B.; Jeyapalan, S.; et al. Cerebrospinal fluid circulating tumor cells as a quantifiable measurement of leptomeningeal metastases in patients with HER2 positive cancer. J. Neurooncol. 2020, 148, 599-606. [CrossRef] [PubMed]

86. De Mattos-Arruda, L.; Mayor, R.; Ng, C.K.Y.; Weigelt, B.; Martínez-Ricarte, F.; Torrejon, D.; Oliveira, M.; Arias, A.; Raventos, C.; Tang, J.; et al. Cerebrospinal fluid-derived circulating tumour DNA better represents the genomic alterations of brain tumours than plasma. Nat. Commun. 2015, 6, 8839. [CrossRef] [PubMed]

87. Momtaz, P.; Pentsova, E.; Abdel-Wahab, O.; Diamond, E.; Hyman, D.; Merghoub, T.; You, D.; Gasmi, B.; Viale, A.; Chapman, P.B. Quantification of tumor-derived cell free DNA(cfDNA) by digital PCR (DigPCR) in cerebrospinal fluid of patients with BRAFV600 mutated malignancies. Oncotarget 2016, 7, 85430-85436. [CrossRef] [PubMed]

88. Pentsova, E.I.; Shah, R.H.; Tang, J.; Boire, A.; You, D.; Briggs, S.; Omuro, A.; Lin, X.; Fleisher, M.; Grommes, C.; et al. Evaluating Cancer of the Central Nervous System Through Next-Generation Sequencing of Cerebrospinal Fluid. J. Clin. Oncol. 2016, 34, 2404-2415. [CrossRef]

89. Marchiò, C.; Mariani, S.; Bertero, L.; Di Bello, C.; Francia Di Celle, P.; Papotti, M.; Rudà, R.; Soffietti, R.; Cassoni, P. Liquoral liquid biopsy in neoplastic meningitis enables molecular diagnosis and mutation tracking: A proof of concept. Neuro Oncol. 2017, 19, 451-453. [CrossRef]

90. Swinkels, D.W.; de Kok, J.B.; Hanselaar, A.; Lamers, K.; Boerman, R.H. Early detection of leptomeningeal metastasis by PCR examination of tumor-derived K-ras DNA in cerebrospinal fluid. Clin. Chem. 2000, 46, 132-133. [CrossRef]

91. Fan, Y.; Zhu, X.; Xu, Y.; Lu, X.; Xu, Y.; Wang, M.; Xu, H.; Ding, J.; Ye, X.; Fang, L.; et al. Cell-Cycle and DNA-Damage Response Pathway Is Involved in Leptomeningeal Metastasis of Non-Small Cell Lung Cancer. Clin. Cancer Res. 2018, 24, 209-216. [CrossRef] [PubMed]

92. Li, Y.S.; Jiang, B.Y.; Yang, J.J.; Zhang, X.C.; Zhang, Z.; Ye, J.Y.; Zhong, W.Z.; Tu, H.Y.; Chen, H.J.; Wang, Z.; et al. Unique genetic profiles from cerebrospinal fluid cell-free DNA in leptomeningeal metastases of EGFR-mutant non-small-cell lung cancer: A new medium of liquid biopsy. Ann. Oncol. 2018, 29, 945-952. [CrossRef]

93. Boire, A.; Brandsma, D.; Brastianos, P.K.; Le Rhun, E.; Ahluwalia, M.; Junck, L.; Glantz, M.; Groves, M.D.; Lee, E.Q.; Lin, N.; et al. Liquid biopsy in central nervous system metastases: A RANO review and proposals for clinical applications. Neuro Oncol. 2019, 21, 571-584. [CrossRef] [PubMed]

94. Huang, R.; Xu, X.; Li, D.; Chen, K.; Zhan, Q.; Ge, M.; Zhou, X.; Liang, X.; Guan, M. Digital PCR-Based Detection of EGFR Mutations in Paired Plasma and CSF Samples of Lung Adenocarcinoma Patients with Central Nervous System Metastases. Target. Oncol. 2019, 14, 343-350. [CrossRef] [PubMed]

95. Ma, C.; Yang, X.; Xing, W.; Yu, H.; Si, T.; Guo, Z. Detection of circulating tumor DNA from non-small cell lung cancer brain metastasis in cerebrospinal fluid samples. Thorac. Cancer 2020, 11, 588-593. [CrossRef] [PubMed]

96. Li, H.; Xie, Y.; Lin, Y.; Yu, T.; Yin, Z. Different Gene Mutation Spectrum of the Paired CSF and Plasma Samples in Lung Adenocarcinoma with Leptomeningeal Metastases: The Liquid Biopsy Based on Circulating Tumor DNA. Chin. J. Lung Cancer 2020, 23, 646-654. [CrossRef]

97. Zheng, M.M.; Li, Y.S.; Tu, H.Y.; Jiang, B.Y.; Yang, J.J.; Zhou, Q.; Xu, C.R.; Yang, X.R.; Wu, Y.L. Genotyping of Cerebrospinal Fluid Associated With Osimertinib Response and Resistance for Leptomeningeal Metastases in EGFR-Mutated NSCLC. J. Thorac. Oncol. 2021, 16, 250-258. [CrossRef]

98. Carausu, M.; Melaabi, S.; Pierga, J.Y.; Bidard, F.C.; Cabel, L. ESR1 Mutation Detection and Dynamics in Meningeal Carcinomatosis in Breast Cancer. J. Breast Cancer 2019, 23, 218-223. [CrossRef] 
99. Angus, L.; Deger, T.; Jager, A.; Martens, J.W.M.; de Weerd, V.; van Heuvel, I.; van den Bent, M.J.; Sillevis Smitt, P.A.; Kros, J.M.; Bindels, E.M.; et al. Detection of aneuploidy in cerebrospinal fluid from patients with breast cancer can improve diagnosis of leptomeningeal metastases. Clin. Cancer Res. 2021, 27, 2798-2806. [CrossRef]

100. Ballester, L.Y.; Glitza Oliva, I.C.; Douse, D.Y.; Chen, M.M.; Lan, C.; Haydu, L.E.; Huse, J.T.; Roy-Chowdhuri, S.; Luthra, R.; Wistuba, I.I.; et al. Evaluating Circulating Tumor DNA From the Cerebrospinal Fluid of Patients With Melanoma and Leptomeningeal Disease. J. Neuropathol. Exp. Neurol. 2018, 77, 628-635. [CrossRef]

101. Smalley, I.; Law, V.; Wyatt, C.; Evernden, B.; Fang, B.; Koomen, J.M.; Welsh, E.A.; Macaulay, R.J.B.; Forsyth, P.A.; Smalley, K.S.M. Proteomic Analysis of CSF from Patients with Leptomeningeal Melanoma Metastases Identifies Signatures Associated with Disease Progression and Therapeutic Resistance. Clin. Cancer Res. 2020, 26, 2163-2175. [CrossRef] [PubMed]

102. Gani, C.; Müller, A.C.; Eckert, F.; Schroeder, C.; Bender, B.; Pantazis, G.; Bamberg, M.; Berger, B. Outcome after whole brain radiotherapy alone in intracranial leptomeningeal carcinomatosis from solid tumors. Strahlenther. Onkol. 2012, 188, 148-153. [CrossRef]

103. Brower, J.V.; Saha, S.; Rosenberg, S.A.; Hullett, C.R.; Ian Robins, H. Management of leptomeningeal metastases: Prognostic factors and associated outcomes. J. Clin. Neurosci. 2016, 27, 130-137. [CrossRef] [PubMed]

104. El Shafie, R.A.; Böhm, K.; Weber, D.; Lang, K.; Schlaich, F.; Adeberg, S.; Paul, A.; Haefner, M.F.; Katayama, S.; Sterzing, F.; et al. Outcome and prognostic factors following palliative craniospinal irradiation for leptomeningeal carcinomatosis. Cancer Manag. Res. 2019, 11, 789-801. [CrossRef] [PubMed]

105. Devecka, M.; Duma, M.N.; Wilkens, J.J.; Kampfer, S.; Borm, K.J.; Münch, S.; Straube, C.; Combs, S.E. Craniospinal irradiation (CSI) in patients with leptomeningeal metastases: Risk-benefit-profile and development of a prognostic score for decision making in the palliative setting. BMC Cancer 2020, 20, 501. [CrossRef] [PubMed]

106. Yang, T.J.; Wijetunga, N.A.; Yamada, J.; Wolden, S.; Mehallow, M.; Goldman, D.A.; Zhang, Z.; Young, R.J.; Kris, M.G.; Yu, H.A.; et al. Clinical trial of proton craniospinal irradiation for leptomeningeal metastases. Neuro Oncol. 2021, 23, 134-143. [CrossRef]

107. Li, Y.S.; Jiang, B.Y.; Yang, J.J.; Tu, H.Y.; Zhou, Q.; Guo, W.B.; Yan, H.H.; Wu, Y.L. Leptomeningeal Metastases in Patients with NSCLC with EGFR Mutations. J. Thorac. Oncol. 2016, 11, 1962-1969. [CrossRef]

108. Kuiper, J.L.; Hendriks, L.E.; van der Wekken, A.J.; de Langen, A.J.; Bahce, I.; Thunnissen, E.; Heideman, D.A.; Berk, Y.; Buijs, E.J.; Speel, E.J.; et al. Treatment and survival of patients with EGFR-mutated non-small cell lung cancer and leptomeningeal metastasis: A retrospective cohort analysis. Lung Cancer 2015, 89, 255-261. [CrossRef]

109. Grommes, C.; Oxnard, G.R.; Kris, M.G.; Miller, V.A.; Pao, W.; Holodny, A.I.; Clarke, J.L.; Lassman, A.B. "Pulsatile” high-dose weekly erlotinib for CNS metastases from EGFR mutant non-small cell lung cancer. Neuro Oncol. 2011, 13, 1364-1369. [CrossRef]

110. Lee, E.; Keam, B.; Kim, D.W.; Kim, T.M.; Lee, S.H.; Chung, D.H.; Heo, D.S. Erlotinib versus gefitinib for control of leptomeningeal carcinomatosis in non-small-cell lung cancer. J. Thorac. Oncol. 2013, 8, 1069-1074. [CrossRef]

111. Yang, H.; Yang, X.; Zhang, Y.; Liu, X.; Deng, Q.; Zhao, M.; Xu, X.; He, J. Erlotinib in combination with pemetrexed/cisplatin for leptomeningeal metastases and cerebrospinal fluid drug concentrations in lung adenocarcinoma patients after gefitinib failure. Target. Oncol. 2015, 10, 135-140. [CrossRef] [PubMed]

112. Kawamura, T.; Hata, A.; Takeshita, J.; Fujita, S.; Hayashi, M.; Tomii, K.; Katakami, N. High-dose erlotinib for refractory leptomeningeal metastases after failure of standard-dose EGFR-TKIs. Cancer Chemother. Pharmacol. 2015, 75, 1261-1266. [CrossRef] [PubMed]

113. Jackman, D.M.; Cioffredi, L.A.; Jacobs, L.; Sharmeen, F.; Morse, L.K.; Lucca, J.; Plotkin, S.R.; Marcoux, P.J.; Rabin, M.S.; Lynch, T.J.; et al. A phase I trial of high dose gefitinib for patients with leptomeningeal metastases from non-small cell lung cancer. Oncotarget 2015, 6, 4527-4536. [CrossRef] [PubMed]

114. Tamiya, A.; Tamiya, M.; Nishihara, T.; Shiroyama, T.; Nakao, K.; Tsuji, T.; Takeuchi, N.; Isa, S.I.; Omachi, N.; Okamoto, N.; et al. Cerebrospinal Fluid Penetration Rate and Efficacy of Afatinib in Patients with EGFR Mutation-positive Non-small Cell Lung Cancer with Leptomeningeal Carcinomatosis: A Multicenter Prospective Study. Anticancer. Res. 2017, 37, 4177-4182. [CrossRef] [PubMed]

115. Yang, J.C.; Cho, B.C.; Kim, D.; Kim, S.W.; Lee, J.S.; Su, W.C.; John, T.; Chuan-Hao Kao, S.; Natale, R.; Wadeet, T.; et al. Osimertinib for patients (pts) with leptomeningeal metastases (LM) from EGFR-mutant non-small cell lung cancer (NSCLC): Updated results from the BLOOM study. Proc. Am. Soc. Clin. Oncol. 2017, 35, 2020. [CrossRef]

116. Nanjo, S.; Hata, A.; Okuda, C.; Kaji, R.; Okada, H.; Tamura, D.; Irie, K.; Okada, H.; Fukushima, S.; Katakami, N. Standard-dose osimertinib for refractory leptomeningeal metastases in T790M-positive EGFR-mutant non-small cell lung cancer. Br. J. Cancer 2018, 118, 32-37. [CrossRef]

117. Yang, J.C.H.; Kim, S.W.; Kim, D.W.; Lee, J.S.; Cho, B.C.; Ahn, J.S.; Lee, D.H.; Kim, T.M.; Goldman, J.W.; Natale, R.B.; et al. Osimertinib in Patients With Epidermal Growth Factor Receptor Mutation-Positive Non-Small-Cell Lung Cancer and Leptomeningeal Metastases: The BLOOM Study. J. Clin. Oncol. 2020, 38, 538-547. [CrossRef]

118. Saboundji, K.; Auliac, J.B.; Pérol, M.; François, G.; Janicot, H.; Marcq, M.; Dubos-Arvis, C.; Renault, A.; Guisier, F.; Odier, L.; et al. Efficacy of Osimertinib in EGFR-Mutated Non-Small Cell Lung Cancer with Leptomeningeal Metastases Pretreated with EGFR-Tyrosine Kinase Inhibitors. Target. Oncol. 2018, 13, 501-507. [CrossRef] 
119. Ahn, M.J.; Chiu, C.H.; Cheng, Y.; Han, J.Y.; Goldberg, S.B.; Greystoke, A.; Crawford, J.; Zhao, Y.; Huang, X.; Johnson, M.; et al. Osimertinib for Patients With Leptomeningeal Metastases Associated With EGFR T790M-Positive Advanced NSCLC: The AURA Leptomeningeal Metastases Analysis. J. Thorac. Oncol. 2020, 15, 637-648. [CrossRef]

120. Park, S.; Lee, M.H.; Seong, M.; Kim, S.T.; Kang, J.H.; Cho, B.C.; Lee, K.H.; Cho, E.K.; Sun, J.M.; Lee, S.H.; et al. A phase II, multicenter, two cohort study of $160 \mathrm{mg}$ osimertinib in EGFR T790M-positive non-small-cell lung cancer patients with brain metastases or leptomeningeal disease who progressed on prior EGFR TKI therapy. Ann. Oncol. 2020, 31, 1397-1404. [CrossRef]

121. Lee, J.; Choi, Y.; Han, J.; Park, S.; Jung, H.A.; Su, J.M.; Lee, S.H.; Ahn, J.S.; Park, K.; Ahn, M.J. Osimertinib Improves Overall Survival in Patients With EGFR-Mutated NSCLC With Leptomeningeal Metastases Regardless of T790M Mutational Status. J. Thorac. Oncol. 2020, 15, 1758-1766. [CrossRef] [PubMed]

122. Okuno, T.; Arakawa, S.; Yoshida, T.; Ohe, Y. Efficacy of osimertinib in a patient with leptomeningeal metastasis and EGFR uncommon S768I mutation. Lung Cancer 2020, 143, 95-96. [CrossRef] [PubMed]

123. Li, H.; Yu, T.; Lin, Y.; Xie, Y.; Feng, J.; Huang, M.; Guo, A.; Liu, X.; Yin, Z. Three Novel EGFR Mutations (750_758del, I759S, T751_I759delinsS) in One Patient with Metastatic Non-Small Cell Lung Cancer Responding to Osimertinib: A Case Report. OncoTargets Ther. 2020, 13, 7941-7948. [CrossRef] [PubMed]

124. Soria, J.C.; Ohe, Y.; Vansteenkiste, J.; Reungwetwattana, T.; Chewaskulyong, B.; Lee, K.H.; Dechaphunkul, A.; Imamura, F.; Nogami, N.; Kurata, T.; et al. Osimertinib in Untreated EGFR-Mutated Advanced Non-Small-Cell Lung Cancer. N. Engl. J. Med. 2018, 378, 113-125. [CrossRef] [PubMed]

125. Choi, M.; Keam, B.; Ock, C.Y.; Kim, M.; Kim, T.M.; Kim, D.W.; Heo, D.S. Pemetrexed in the Treatment of Leptomeningeal Metastasis in Patients With EGFR-mutant Lung Cancer. Clin. Lung Cancer 2019, 20, e442-e451. [CrossRef] [PubMed]

126. Jänne, P.; Planchard, D.; Howarth, P.; Todd, A.; Kobayashidoi, K. OA07.01 Osimertinib Plus Platinum/Pemetrexed in Newly Diagnosed Advanced EGFRm-Positive NSCLC; The Phase 3 FLAURA2 Study. J. Thorac. Oncol. 2019, 14, S222-S223. [CrossRef]

127. Jing, W.; Wang, H.; Kong, L.; Yu, J.; Zhu, H. Great efficacy of bevacizumab plus erlotinib for leptomeningeal metastases from non-small cell lung cancer with initially positive EGFR mutation: A case report. Cancer Biol. Ther. 2018, 19, 1073-1077. [CrossRef]

128. Jiang, T.; Xu, X.; Chen, X.; Ding, N.; Hu, Q.; Zhou, C.; Hu, J. Osimertinib in combination with bevacizumab in EGFR-Mutated NSCLC with leptomeningeal metastases. Transl. Lung Cancer Res. 2020, 9, 2514-2517. [CrossRef]

129. Liao, B.C.; Lee, J.H.; Lin, C.C.; Chen, Y.F.; Chang, C.H.; Ho, C.C.; Shih, J.Y.; Yu, C.J.; Yang, J.C. Epidermal Growth Factor Receptor Tyrosine Kinase Inhibitors for Non-Small-Cell Lung Cancer Patients with Leptomeningeal Carcinomatosis. J. Thorac. Oncol. 2015, 10, 1754-1761. [CrossRef]

130. Ahn, M.J.; Kim, D.W.; Cho, B.C.; Kim, S.W.; Lee, J.S.; Ahn, J.S.; Kim, T.M.; Lin, C.C.; Kim, H.R.; John, T.; et al. Activity and safety of AZD3759 in EGFR-mutant non-small-cell lung cancer with CNS metastases (BLOOM): A phase 1, open-label, dose-escalation and dose-expansion study. Lancet Respir. Med. 2017, 5, 891-902. [CrossRef]

131. Cho, B.C.; Ahn, M.; Lee, J.; Kim, D.W.; Kim, S.W.; John, T.; Kao, S.C.-H.; Goldman, J.W.; Su, W.-C.; Natale, R.B.; et al. Phase I study (BLOOM) of AZD3759, a BBB penetrable EGFR inhibitor, in EGFRm NSCLC patients with leptomeningeal metastasis (LM) who progressed after other anticancer therapy. J. Clin. Oncol. 2017, 35, 2069. [CrossRef]

132. Xu, H.; Zhou, L.; Lu, Y.; Su, X.; Cheng, P.; Li, D.; Gao, H.; Li, H.; Yuan, W.; Zhang, L.; et al. Dual Targeting of the Epidermal Growth Factor Receptor Using Combination of Nimotuzumab and Erlotinib in Advanced Non-Small-Cell Lung Cancer with Leptomeningeal Metastases: A Report of Three Cases. OncoTargets Ther. 2020, 13, 647-656. [CrossRef] [PubMed]

133. Costa, D.B.; Kobayashi, S.; Pandya, S.S.; Yeo, W.L.; Shen, Z.; Tan, W.; Wilner, K.D. CSF concentration of the anaplastic lymphoma kinase inhibitor crizotinib. J. Clin. Oncol. 2011, 29, e443-e445. [CrossRef] [PubMed]

134. Ahn, H.K.; Han, B.; Lee, S.J.; Lim, T.; Sun, J.M.; Ahn, J.S.; Ahn, M.J.; Park, K. ALK inhibitor crizotinib combined with intrathecal methotrexate treatment for non-small cell lung cancer with leptomeningeal carcinomatosis. Lung Cancer 2012, 76, 253-254. [CrossRef]

135. Arrondeau, J.; Ammari, S.; Besse, B.; Soria, J.C. LDK378 compassionate use for treating carcinomatous meningitis in an ALK translocated non-small-cell lung cancer. J. Thorac. Oncol. 2014, 9, e62-e63. [CrossRef] [PubMed]

136. Dudnik, E.; Siegal, T.; Zach, L.; Allen, A.M.; Flex, D.; Yust-Katz, S.; Limon, D.; Hirsch, F.R.; Peled, N. Durable brain response with pulse-dose crizotinib and ceritinib in ALK-positive non-small cell lung cancer compared with brain radiotherapy. J. Clin. Neurosci. 2016, 26, 46-49. [CrossRef]

137. Gainor, J.F.; Sherman, C.A.; Willoughby, K.; Logan, J.; Kennedy, E.; Brastianos, P.K.; Chi, A.S.; Shaw, A.T. Alectinib salvages CNS relapses in ALK-positive lung cancer patients previously treated with crizotinib and ceritinib. J. Thorac. Oncol. 2015, 10, 232-236. [CrossRef]

138. Ou, S.H.; Sommers, K.R.; Azada, M.C.; Garon, E.B. Alectinib induces a durable (>15 months) complete response in an ALKpositive non-small cell lung cancer patient who progressed on crizotinib with diffuse leptomeningeal carcinomatosis. Oncologist 2015, 20, 224-226. [CrossRef]

139. Gainor, J.F.; Chi, A.S.; Logan, J.; Hu, R.; Oh, K.S.; Brastianos, P.K.; Shih, H.A.; Shaw, A.T. Alectinib Dose Escalation Reinduces Central Nervous System Responses in Patients with Anaplastic Lymphoma Kinase-Positive Non-Small Cell Lung Cancer Relapsing on Standard Dose Alectinib. J. Thorac. Oncol. 2016, 11, 256-260. [CrossRef]

140. Gaye, E.; Geier, M.; Bore, P.; Guilloïque, M.; Lucia, F.; Quéré, G.; Gouva, S.; Robinet, G.; Descourt, R. Intra-cranial efficacy of brigatinib in an ALK-positive non-small cell lung cancer patient presenting leptomeningeal carcinomatosis. Lung Cancer 2019, 133, 1-3. [CrossRef] 
141. Pellerino, A.; Buffoni, L.; Rudà, R.; Soffietti, R. Complete response of spinal metastases from non-small cell lung cancer with ALK inhibitors. Neurology 2019, 93, 217-219. [CrossRef]

142. Frost, N.; Christopoulos, P.; Kauffmann-Guerrero, D.; Stratmann, J.; Riedel, R.; Schaefer, M.; Alt, J.; Gütz, S.; Christoph, D.C.; Laack, E.; et al. Lorlatinib in pretreated ALK- or ROS1-positive lung cancer and impact of TP53 co-mutations: Results from the German early access program. Ther. Adv. Med. Oncol. 2021, 13, 1758835920980558. [CrossRef]

143. Gainor, J.F.; Ou, S.H.; Logan, J.; Borges, L.F.; Shaw, A.T. The central nervous system as a sanctuary site in ALK-positive non-small-cell lung cancer. J. Thorac. Oncol. 2013, 8, 1570-1573. [CrossRef]

144. Crinò, L.; Ahn, M.J.; De Marinis, F.; Groen, H.J.; Wakelee, H.; Hida, T.; Mok, T.; Spigel, D.; Felip, E.; Nishio, M.; et al. Multicenter Phase II Study of Whole-Body and Intracranial Activity With Ceritinib in Patients With ALK-Rearranged Non-Small-Cell Lung Cancer Previously Treated With Chemotherapy and Crizotinib: Results From ASCEND-2. J. Clin. Oncol. 2016, 34, $2866-2873$. [CrossRef] [PubMed]

145. Shaw, A.T.; Kim, T.M.; Crinò, L.; Gridelli, C.; Kiura, K.; Liu, G.; Novello, S.; Bearz, A.; Gautschi, O.; Mok, T.; et al. Ceritinib versus chemotherapy in patients with ALK-rearranged non-small-cell lung cancer previously given chemotherapy and crizotinib (ASCEND-5): A randomised, controlled, open-label, phase 3 trial. Lancet Oncol. 2017, 18, 874-886. [CrossRef]

146. Chow, L.Q.; Barlesi, F.; Bertino, E.M.; van den Bent, M.J.; Wakelee, H.; Wen, P.Y.; Chiu, C.H.; Orlov, S.; Majem, M.; Chiari, R.; et al. Results of the ASCEND-7 phase II study evaluating ALK inhibitor ceritinib in patients with ALK+ non-small cell lung cancer metastatic to the brain. Ann. Oncol. 2019, 30, v602-v603. [CrossRef]

147. Camidge, D.R.; Dziadziuszko, R.; Peters, S.; Mok, T.; Noe, J.; Nowicka, M.; Gadgeel, S.M.; Cheema, P.; Pavlakis, N.; de Marinis, F.; et al. Updated Efficacy and Safety Data and Impact of the EML4-ALK Fusion Variant on the Efficacy of Alectinib in Untreated ALK-Positive Advanced Non-Small Cell Lung Cancer in the Global Phase III ALEX Study. J. Thorac. Oncol. 2019, 14, 1233-1243. [CrossRef] [PubMed]

148. Camidge, D.R.; Kim, H.R.; Ahn, M.J.; Yang, J.C.H.; Han, J.Y.; Hochmair, M.J.; Lee, K.H.; Delmonte, A.; García Campelo, M.R.; Kim, D.W.; et al. Brigatinib Versus Crizotinib in Advanced ALK Inhibitor-Naive ALK-Positive Non-Small Cell Lung Cancer: Second Interim Analysis of the Phase III ALTA-1L Trial. J. Clin. Oncol. 2020, 38, 3592-3603. [CrossRef] [PubMed]

149. Ando, K.; Akimoto, K.; Sato, H.; Manabe, R.; Kishino, Y.; Homma, T.; Kusumoto, S.; Yamaoka, T.; Tanaka, A.; Ohmori, T.; et al. Brigatinib and Alectinib for ALK Rearrangement-Positive Advanced Non-Small Cell Lung Cancer With or Without Central Nervous System Metastasis: A Systematic Review and Network Meta-Analysis. Cancers 2020, 12, 942. [CrossRef] [PubMed]

150. Shaw, A.T.; Solomon, B.J.; Chiari, R.; Riely, G.J.; Besse, B.; Soo, R.A.; Kao, S.; Lin, C.C.; Bauer, T.M.; Clancy, J.S.; et al. Lorlatinib in advanced ROS1-positive non-small-cell lung cancer: A multicentre, open-label, single-arm, phase 1-2 trial. Lancet Oncol. 2019, 20, 1691-1701. [CrossRef]

151. Shaw, A.T.; Bauer, T.M.; de Marinis, F.; Felip, E.; Goto, Y.; Liu, G.; Mazieres, J.; Kim, D.W.; Mok, T.; Polli, A.; et al. First-Line Lorlatinib or Crizotinib in Advanced ALK-Positive Lung Cancer. N. Engl. J. Med. 2020, 383, 2018-2029. [CrossRef]

152. Cardoso, F.; Paluch-Shimon, S.; Senkus, E.; Curigliano, G.; Aapro, M.S.; André, F.; Barrios, C.H.; Bergh, J.; Bhattacharyya, G.S.; Biganzoli, L.; et al. 5th ESO-ESMO international consensus guidelines for advanced breast cancer (ABC 5). Ann. Oncol. 2020, 31, 1623-1649. [CrossRef] [PubMed]

153. Lee, S.; Ahn, H.K.; Park, Y.H.; Nam, D.H.; Lee, J.I.; Park, W.; Choi, D.H.; Huh, S.J.; Park, K.T.; Ahn, J.S.; et al. Leptomeningeal metastases from breast cancer: Intrinsic subtypes may affect unique clinical manifestations. Breast Cancer Res. Treat. 2011, 129, 809-817. [CrossRef] [PubMed]

154. Lin, N.U.; Vanderplas, A.; Hughes, M.E.; Theriault, R.L.; Edge, S.B.; Wong, Y.N.; Blayney, D.W.; Niland, J.C.; Winer, E.P.; Weeks, J.C. Clinicopathologic features, patterns of recurrence, and survival among women with triple-negative breast cancer in the National Comprehensive Cancer Network. Cancer 2012, 118, 5463-5472. [CrossRef]

155. Kennecke, H.; Yerushalmi, R.; Woods, R.; Cheang, M.C.; Voduc, D.; Speers, C.H.; Nielsen, T.O.; Gelmon, K. Metastatic behavior of breast cancer subtypes. J. Clin. Oncol. 2010, 28, 3271-3277. [CrossRef]

156. Mehta, A.I.; Brufsky, A.M.; Sampson, J.H. Therapeutic approaches for HER2-positive brain metastases: Circumventing the blood-brain barrier. Cancer Treat. Rev. 2013, 39, 261-269. [CrossRef] [PubMed]

157. Stemmler, H.J.; Schmitt, M.; Willems, A.; Bernhard, H.; Harbeck, N.; Heinemann, V. Ratio of trastuzumab levels in serum and cerebrospinal fluid is altered in HER2-positive breast cancer patients with brain metastases and impairment of blood-brain barrier. Anticancer Drugs 2007, 18, 23-28. [CrossRef] [PubMed]

158. Dijkers, E.C.; Oude Munnink, T.H.; Kosterink, J.G.; Brouwers, A.H.; Jager, P.L.; de Jong, J.R.; van Dongen, G.A.; Schröder, C.P.; Lub-de Hooge, M.N.; de Vries, E.G. Biodistribution of 89Zr-trastuzumab and PET imaging of HER2-positive lesions in patients with metastatic breast cancer. Clin. Pharmacol. Ther. 2010, 87, 586-592. [CrossRef]

159. Figura, N.B.; Rizk, V.T.; Mohammadi, H.; Evernden, B.; Mokhtari, S.; Yu, H.M.; Robinson, T.J.; Etame, A.B.; Tran, N.D.; Liu, J.; et al. Clinical outcomes of breast leptomeningeal disease treated with intrathecal trastuzumab, intrathecal chemotherapy, or whole brain radiation therapy. Breast Cancer Res. Treat. 2019, 175, 781-788. [CrossRef]

160. Zagouri, F.; Zoumpourlis, P.; Le Rhun, E.; Bartsch, R.; Zografos, E.; Apostolidou, K.; Dimopoulos, M.A.; Preusser, M. Intrathecal administration of anti-HER2 treatment for the treatment of meningeal carcinomatosis in breast cancer: A metanalysis with meta-regression. Cancer Treat. Rev. 2020, 88, 102046. [CrossRef] 
161. Grossman, S.A.; Finkelstein, D.M.; Ruckdeschel, J.C.; Trump, D.L.; Moynihan, T.; Ettinger, D.S. Randomized prospective comparison of intraventricular methotrexate and thiotepa in patients with previously untreated neoplastic meningitis. Eastern Cooperative Oncology Group. J. Clin. Oncol. 1993, 11, 561-569. [CrossRef]

162. Hitchins, R.N.; Bell, D.R.; Woods, R.L.; Levi, J.A. A prospective randomized trial of single-agent versus combination chemotherapy in meningeal carcinomatosis. J. Clin. Oncol. 1987, 5, 1655-1662. [CrossRef] [PubMed]

163. Glantz, M.J.; Jaeckle, K.A.; Chamberlain, M.C.; Phuphanich, S.; Recht, L.; Swinnen, L.J.; Maria, B.; LaFollette, S.; Schumann, G.B.; Cole, B.F.; et al. A randomized controlled trial comparing intrathecal sustained-release cytarabine (DepoCyt) to intrathecal methotrexate in patients with neoplastic meningitis from solid tumors. Clin. Cancer Res. 1999, 5, 3394-3402. [PubMed]

164. Boogerd, W.; van den Bent, M.J.; Koehler, P.J.; Heimans, J.J.; van der Sande, J.J.; Aaronson, N.K.; Hart, A.A.; Benraadt, J.; Vecht, C.J. The relevance of intraventricular chemotherapy for leptomeningeal metastasis in breast cancer: A randomised study. Eur. J. Cancer 2004, 40, 2726-2733. [CrossRef] [PubMed]

165. Le Rhun, E.; Mailliez, A.; Wallet, J.; Rodrigues, I.; Boulanger, T.; Desmoulins, I.; Barriere, J.; Fabbro, M.; Taillibert, S.; Andre, C.; et al. 371O. Intra-CSF liposomal cytarabine plus systemic therapy as initial treatment of breast cancer leptomeningeal metastasis: A randomised, open-label trial. Ann. Oncol. 2018, 29, viii122-viii132. [CrossRef]

166. Swain, S.M.; Baselga, J.; Kim, S.B.; Ro, J.; Semiglazov, V.; Campone, M.; Ciruelos, E.; Ferrero, J.M.; Schneeweiss, A.; Heeson, S.; et al. Pertuzumab, trastuzumab, and docetaxel in HER2-positive metastatic breast cancer. N. Engl. J. Med. 2015, 372, 724-734. [CrossRef]

167. Jacot, W.; Pons, E.; Frenel, J.S.; Guiu, S.; Levy, C.; Heudel, P.E.; Bachelot, T.; D’Hondt, V.; Darlix, A.; Firmin, N.; et al. Efficacy and safety of trastuzumab emtansine (T-DM1) in patients with HER2-positive breast cancer with brain metastases. Breast Cancer Res. Treat. 2016, 157, 307-318. [CrossRef] [PubMed]

168. Diéras, V.; Miles, D.; Verma, S.; Pegram, M.; Welslau, M.; Baselga, J.; Krop, I.E.; Blackwell, K.; Hoersch, S.; Xu, J.; et al. Trastuzumab emtansine versus capecitabine plus lapatinib in patients with previously treated HER2-positive advanced breast cancer (EMILIA): A descriptive analysis of final overall survival results from a randomised, open-label, phase 3 trial. Lancet Oncol. 2017, 18, 732-742. [CrossRef]

169. Montemurro, F.; Delaloge, S.; Barrios, C.H.; Wuerstlein, R.; Anton, A.; Brain, E.; Hatschek, T.; Kelly, C.M.; Peña-Murillo, C.; Yilmaz, M.; et al. Trastuzumab emtansine (T-DM1) in patients with HER2-positive metastatic breast cancer and brain metastases: Exploratory final analysis of cohort 1 from KAMILLA, a single-arm phase IIIb clinical trial`̌. Ann. Oncol. 2020, 31, 1350-1358. [CrossRef]

170. Ricciardi, G.R.R.; Russo, A.; Franchina, T.; Schifano, S.; Mastroeni, G.; Santacaterina, A.; Adamo, V. Efficacy of T-DM1 for leptomeningeal and brain metastases in a HER2 positive metastatic breast cancer patient: New directions for systemic therapy-a case report and literature review. BMC Cancer 2018, 18, 97. [CrossRef]

171. Freedman, R.A.; Gelman, R.S.; Anders, C.K.; Melisko, M.E.; Parsons, H.A.; Cropp, A.M.; Silvestri, K.; Cotter, C.M.; Componeschi, K.P.; Marte, J.M.; et al. Translational Breast Cancer Research Consortium. TBCRC 022: A Phase II Trial of Neratinib and Capecitabine for Patients With Human Epidermal Growth Factor Receptor 2-Positive Breast Cancer and Brain Metastases. J. Clin. Oncol. 2019, 37, 1081-1089. [CrossRef]

172. Saura, C.; Oliveira, M.; Feng, Y.H.; Dai, M.S.; Chen, S.W.; Hurvitz, S.A.; Kim, S.B.; Moy, B.; Delaloge, S.; Gradishar, W.; et al. NALA Investigators. Neratinib Plus Capecitabine Versus Lapatinib Plus Capecitabine in HER2-Positive Metastatic Breast Cancer Previously Treated With $\geq 2$ HER2-Directed Regimens: Phase III NALA Trial. J. Clin. Oncol. 2020, 38, 3138-3149. [CrossRef]

173. Murthy, R.K.; Loi, S.; Okines, A.; Paplomata, E.; Hamilton, E.; Hurvitz, S.A.; Lin, N.U.; Borges, V.; Abramson, V.; Anders, C.; et al. Tucatinib, Trastuzumab, and Capecitabine for HER2-Positive Metastatic Breast Cancer. N. Engl. J. Med. 2020, 382, 597-609. [CrossRef] [PubMed]

174. Pellerino, A.; Palmiero, R.; Mo, F.; Bruno, F.; Muscolino, E.; Franchino, F.; Rudà, R.; Soffietti, R. Neratinib for treatment of leptomeningeal metastases from HER2-positive breast cancer in extended access program: Preliminary results. Neurol. Sci. 2020, 41, S264.

175. Chen, T.W.; Jan, I.S.; Chang, D.Y.; Lin, C.H.; Chen, I.C.; Chen, H.M.; Cheng, A.L.; Lu, Y.S. Systemic treatment of breast cancer with leptomeningeal metastases using bevacizumab, etoposide and cisplatin (BEEP regimen) significantly improves overall survival. $J$. Neurooncol. 2020, 148, 165-172. [CrossRef] [PubMed]

176. Boogerd, W.; Dorresteijn, L.D.; van Der Sande, J.J.; de Gast, G.C.; Bruning, P.F. Response of leptomeningeal metastases from breast cancer to hormonal therapy. Neurology 2000, 55, 117-119. [CrossRef]

177. Ozdogan, M.; Samur, M.; Bozcuk, H.S.; Sagtas, E.; Yildiz, M.; Artac, M.; Savas, B. Durable remission of leptomeningeal metastasis of breast cancer with letrozole: A case report and implications of biomarkers on treatment selection. Jpn. J. Clin. Oncol. 2003, 33, 229-231. [CrossRef]

178. Navarro Martín, L.M.; Ocaña Fernández, A.; Rodríguez Sánchez, C.A.; Ruiz Martín, I.; Cruz Hernández, J.J. Durable clinical benefit with exemestane in leptomeningeal metastasis of breast cancer. Clin. Transl. Oncol. 2005, 7, 358-360. [CrossRef]

179. Zoghi, B.; Elledge, R. Endocrine Therapy for Leptomeningeal Metastases from ER-Positive Breast Cancer: Case Report and a Review of the Literature. Breast J. 2016, 22, 218-223. [CrossRef] [PubMed]

180. Nguyen, L.V.; Searle, K.; Jerzak, K.J. Central nervous system-specific efficacy of CDK4/6 inhibitors in randomized controlled trials for metastatic breast cancer. Oncotarget 2019, 10, 6317-6322. [CrossRef] 
181. Tolaney, S.M.; Sahebjam, S.; Le Rhun, E.; Bachelot, T.; Kabos, P.; Awada, A.; Yardley, D.; Chan, A.; Conte, P.; Diéras, V.; et al. A Phase II Study of Abemaciclib in Patients with Brain Metastases Secondary to Hormone Receptor-Positive Breast Cancer. Clin. Cancer Res. 2020, 26, 5310-5319. [CrossRef]

182. Brastianos, P.K.; Kim, A.E.; Wang, N.; Lee, E.Q.; Ligibel, J.; Cohen, J.V.; Chukwueke, U.N.; Mahar, M.; Oh, K.; White, M.D.; et al. Palbociclib demonstrates intracranial activity in progressive brain metastases harboring cyclin-dependent kinase pathway alterations. Nat. Cancer 2021, 2, 498-502. [CrossRef]

183. Anders, C.; Deal, A.M.; Abramson, V.; Liu, M.C.; Storniolo, A.M.; Carpenter, J.T.; Puhalla, S.; Nanda, R.; Melhem-Bertrandt, A.; Lin, N.U.; et al. TBCRC 018: Phase II study of iniparib in combination with irinotecan to treat progressive triple negative breast cancer brain metastases. Breast Cancer Res. Treat. 2014, 146, 557-566. [CrossRef]

184. Litton, J.K.; Hurvitz, S.A.; Mina, L.A.; Rugo, H.S.; Lee, K.H.; Gonçalves, A.; Diab, S.; Woodward, N.; Goodwin, A.; Yerushalmi, R.; et al. Talazoparib versus chemotherapy in patients with germline BRCA1/2-mutated HER2-negative advanced breast cancer: Final overall survival results from the EMBRACA trial. Ann. Oncol. 2020, 31, 1526-1535. [CrossRef]

185. Bangham, M.; Goldstein, R.; Walton, H.; Ledermann, J.A. Olaparib treatment for BRCA-mutant ovarian cancer with leptomeningeal disease. Gynecol. Oncol. Rep. 2016, 18, 22-24. [CrossRef]

186. Exman, P.; Mallery, R.M.; Lin, N.U.; Parsons, H.A. Response to Olaparib in a Patient with Germline BRCA2 Mutation and Breast Cancer Leptomeningeal Carcinomatosis. NPJ Breast Cancer 2019, 5, 46. [CrossRef]

187. Schmid, P.; Adams, S.; Rugo, H.S.; Schneeweiss, A.; Barrios, C.H.; Iwata, H.; Diéras, V.; Hegg, R.; Im, S.A.; Shaw Wright, G.; et al. IMpassion130 Trial Investigators. Atezolizumab and Nab-Paclitaxel in Advanced Triple-Negative Breast Cancer. N. Engl. J. Med. 2018, 379, 2108-2121. [CrossRef]

188. Brastianos, P.K.; Lee, E.Q.; Cohen, J.V.; Tolaney, S.M.; Lin, N.U.; Wang, N.; Chukwueke, U.; White, M.D.; Nayyar, N.; Kim, A.; et al. Single-arm, open-label phase 2 trial of pembrolizumab in patients with leptomeningeal carcinomatosis. Nat. Med. 2020, 26, 1280-1284. [CrossRef]

189. Kumthekar, P.; Tang, S.C.; Brenner, A.J.; Kesari, S.; Piccioni, D.E.; Anders, C.; Carrillo, J.; Chalasani, P.; Kabos, P.; Puhalla, S.; et al. ANG1005, a Brain-Penetrating Peptide-Drug Conjugate, Shows Activity in Patients with Breast Cancer with Leptomeningeal Carcinomatosis and Recurrent Brain Metastases. Clin. Cancer Res. 2020, 26, 2789-2799. [CrossRef]

190. Arasaratnam, M.; Hong, A.; Shivalingam, B.; Wheeler, H.; Guminksi, A.D.; Long, G.V.; Menzies, A.M. Leptomeningeal melanomaA case series in the era of modern systemic therapy. Pigment Cell Melanoma Res. 2018, 31, 120-124. [CrossRef]

191. Sakji-Dupré, L.; Le Rhun, E.; Templier, C.; Desmedt, E.; Blanchet, B.; Mortier, L. Cerebrospinal fluid concentrations of vemurafenib in patients treated for brain metastatic BRAF-V600 mutated melanoma. Melanoma Res. 2015, 25, 302-305. [CrossRef] [PubMed]

192. Floudas, C.S.; Chandra, A.B.; Xu, Y. Vemurafenib in leptomeningeal carcinomatosis from melanoma: A case report of nearcomplete response and prolonged survival. Melanoma Res. 2016, 26, 312-315. [CrossRef]

193. Lee, J.M.; Mehta, U.N.; Dsouza, L.H.; Guadagnolo, B.A.; Sanders, D.L.; Kim, K.B. Long-term stabilization of leptomeningeal disease with whole-brain radiation therapy in a patient with metastatic melanoma treated with vemurafenib: A case report. Melanoma Res. 2013, 23, 175-178. [CrossRef] [PubMed]

194. Schäfer, N.; Scheffler, B.; Stuplich, M.; Schaub, C.; Kebir, S.; Rehkämper, C.; Mack, F.; Niehusmann, P.; Simon, M.; Greschus, S.; et al. Vemurafenib for leptomeningeal melanomatosis. J. Clin. Oncol. 2013, 31, e173-e174. [CrossRef]

195. Kim, D.W.; Barcena, E.; Mehta, U.N.; Rohlfs, M.L.; Kumar, A.J.; Penas-Prado, M.; Kim, K.B. Prolonged survival of a patient with metastatic leptomeningeal melanoma treated with BRAF inhibition-based therapy: A case report. BMC Cancer 2015, 15, 400. [CrossRef] [PubMed]

196. Wilgenhof, S.; Neyns, B. Complete Cytologic Remission of V600E BRAF-Mutant Melanoma-Associated Leptomeningeal Carcinomatosis Upon Treatment With Dabrafenib. J. Clin. Oncol. 2015, 33, e109-e111. [CrossRef] [PubMed]

197. Glitza, I.C.; Ferguson, S.D.; Guha-Thakurta, N. Rapid resolution of leptomeningeal disease with targeted therapy in a metastatic melanoma patient. J. Neurooncol. 2017, 133, 663-665. [CrossRef]

198. Davies, M.A.; Saiag, P.; Robert, C.; Grob, J.J.; Flaherty, K.T.; Arance, A.; Chiarion-Sileni, V.; Thomas, L.; Lesimple, T.; Mortier, L.; et al. Dabrafenib plus trametinib in patients with BRAFV600-mutant melanoma brain metastases (COMBI-MB): A multicentre, multicohort, open-label, phase 2 trial. Lancet Oncol. 2017, 18, 863-873. [CrossRef]

199. Tétu, P.; Sirven-Villaros, L.; Cuzzubbo, S.; Ursu, R.; Baroudjian, B.; Delyon, J.; Nataf, F.; De Margerie-Mellon, C.; Allayous, C.; Lefevre, W.; et al. Impact of New Systemic Treatment and Radiotherapy in Melanoma Patients with Leptomeningeal Metastases. Cancers 2020, 12, 2635. [CrossRef]

200. Smalley, K.S.; Fedorenko, I.V.; Kenchappa, R.S.; Sahebjam, S.; Forsyth, P.A. Managing leptomeningeal melanoma metastases in the era of immune and targeted therapy. Int. J. Cancer 2016, 139, 1195-1201. [CrossRef] [PubMed]

201. Long, G.V.; Atkinson, V.; Lo, S.; Sandhu, S.; Guminski, A.D.; Brown, M.P.; Wilmott, J.S.; Edwards, J.; Gonzalez, M.; Scolyer, R.A.; et al. Combination nivolumab and ipilimumab or nivolumab alone in melanoma brain metastases: A multicentre randomised phase 2 study. Lancet Oncol. 2018, 19, 672-681. [CrossRef]

202. Glitza, I.C.; Rohlfs, M.; Bassett, R.L.; Ida, J.; Richard, J.; Iqbal, M.; Bernzen, T.; Gerber, D.; Lacey, C.; Diab, A.; et al. ICMT-07 Therapeutic outcomes of intrathecal IL-2 in metastatic melanoma patients with leptomeningeal disease. Soc. Neuro Oncol. 2015, $17, \mathrm{v} 108$.

203. Clemons-Miller, A.R.; Chatta, G.S.; Hutchins, L.; Angtuaco, E.J.; Ravaggi, A.; Santin, A.D.; Cannon, M.J. Intrathecal cytotoxic T-cell immunotherapy for metastatic leptomeningeal melanoma. Clin. Cancer Res. 2001, 7, 917s-924s. 
204. Glitza, I.C.; Haymaker, C.; Bernatchez, C.; Vence, L.; Rohlfs, M.; Richard, J.; Lacey, C.; Mansaray, R.; Fulbright, O.J.; Ramachandran, R.; et al. Intrathecal Administration of Tumor-Infiltrating Lymphocytes Is Well Tolerated in a Patient with Leptomeningeal Disease from Metastatic Melanoma: A Case Report. Cancer Immunol. Res. 2015, 3, 1201-1206. [CrossRef]

205. Glitza, I.C.; Phillips, S.; Brown, C.; Haymaker, C.L.; Bassett, R.L.; Lee, J.J.; Rohlfs, M.L.; Richard, J.; Iqbal, M.; John, I.; et al. Single-center phase I/Ib study of concurrent intrathecal (IT) and intravenous (IV) nivolumab (N) for metastatic melanoma (MM) patients (pts) with leptomeningeal disease (LMD). J. Clin. Oncol. 2020, 38, 10008. [CrossRef]

206. Sonabend, A.M.; Stupp, R. Overcoming the Blood-Brain Barrier with an Implantable Ultrasound Device. Clin. Cancer Res. 2019, 25, 3750-3752. [CrossRef]

207. Idbaih, A.; Canney, M.; Belin, L.; Desseaux, C.; Vignot, A.; Bouchoux, G.; Asquier, N.; Law-Ye, B.; Leclercq, D.; Bissery, A.; et al. Safety and Feasibility of Repeated and Transient Blood-Brain Barrier Disruption by Pulsed Ultrasound in Patients with Recurrent Glioblastoma. Clin. Cancer Res. 2019, 25, 3793-3801. [CrossRef]

208. Rothwell, W.T.; Bell, P.; Richman, L.K.; Limberis, M.P.; Tretiakova, A.P.; Li, M.; Wilson, J.M. Intrathecal Viral Vector Delivery of Trastuzumab Prevents or Inhibits Tumor Growth of Human HER2-Positive Xenografts in Mice. Cancer Res. 2018, 78, 6171-6182. [CrossRef] [PubMed]

209. Boire, A.; Brastianos, P.K.; Garzia, L.; Valiente, M. Brain metastasis. Nat. Rev. Cancer 2020, 20, 4-11. [CrossRef] 